\title{
Review \\ Functional Interplay between Methyltransferases and Inflammasomes in Inflammatory Responses and Diseases
}

\author{
Young-Su Yi $\mathbb{C}$
}

check for updates

Citation: Yi, Y.-S. Functional

Interplay between Methyltransferases and Inflammasomes in Inflammatory Responses and Diseases. Int. J. Mol. Sci. 2021, 22, 7580. https://doi.org/ $10.3390 /$ ijms 22147580

Academic Editors: Amedeo Amedei and A. Phillip West

Received: 17 June 2021

Accepted: 13 July 2021

Published: 15 July 2021

Publisher's Note: MDPI stays neutral with regard to jurisdictional claims in published maps and institutional affiliations.

Copyright: (C) 2021 by the author. Licensee MDPI, Basel, Switzerland. This article is an open access article distributed under the terms and conditions of the Creative Commons Attribution (CC BY) license (https:/ / creativecommons.org/licenses/by/ $4.0 /)$.
Department of Life Sciences, Kyonggi University, Suwon 16227, Korea; ysyi@kgu.ac.kr; Tel.: +82-31-249-9644

\begin{abstract}
An inflammasome is an intracellular protein complex that is activated in response to a pathogenic infection and cellular damage. It triggers inflammatory responses by promoting inflammatory cell death (called pyroptosis) and the secretion of pro-inflammatory cytokines, interleukin (IL)-1 $\beta$ and IL-18. Many types of inflammasomes have been identified and demonstrated to play a central role in inducing inflammatory responses, leading to the onset and progression of numerous inflammatory diseases. Methylation is a biological process by which methyl groups are transferred from methyl donors to proteins, nucleic acids, and other cellular molecules. Methylation plays critical roles in various biological functions by modulating gene expression, protein activity, protein localization, and molecular stability, and aberrant regulation of methylation causes deleterious outcomes in various human diseases. Methylation is a key determinant of inflammatory responses and diseases. This review highlights the current understanding of the functional relationship between inflammasome regulation and methylation of cellular molecules in inflammatory responses and diseases.
\end{abstract}

Keywords: methyltransferase; methylation; epigenetics; inflammasome; DNA; histone

\section{Introduction}

Inflammation is an innate immune response that protects the body from microbial infection and cellular stress [1,2]. The inflammatory response relies on pattern-recognition receptors (PRRs) by recognition of a variety of pathogen-associated molecular patterns (PAMPs) and danger-associated molecular patterns (DAMPs) through receptor-ligand interaction [1,2]. The inflammatory response comprises two steps: priming and triggering. Priming is a preparatory step in the inflammatory response, and involves the inducing of the transcription of pro-inflammatory molecules. It occurs via the cell surface and endosomal PRRs, such as toll-like receptors (TLRs) that activate nuclear factor-kappa B (NF-kB), activator protein-1 (AP-1), and interferon (IFN)-regulatory factors (IRFs) [3-5]. Triggering, on the other hand, is an activation step of the inflammatory response, which involves the activation of inflammasomes, intracellular protein complexes comprising PRRs and inflammatory molecules and typically occurs via intracellular PRRs, such as the nucleotide-binding oligomerization domain (NOD)-like receptors (NLRs), absent in melanoma 2 (AIM2), and inflammatory caspases, mouse caspase-11, human caspase-4, and caspase-5 [6-11]. Inflammasome activation is a key feature of the triggering step of inflammatory responses, and dysregulation of inflammasome activation has been considered the key risk factor for chronic inflammation and numerous human diseases [12-16].

Posttranslational modifications (PTMs) are critical determinants of innate immunity and inflammatory responses $[17,18]$. The functional cooperation between inflammasomes and PTMs has been demonstrated to play pivotal roles in various biological functions. PTMs occur in the components of inflammasomes and regulate the activities and functions of inflammasomes [19-21].

Methylation is a biological process by which methyl groups are added to a subset of proteins and nucleic acids, which leads to the epigenetic modifications of these cellular 
molecules. These molecules achieve the functions required for cellular homeostasis via methylation; therefore, changes in the methylation status have been implicated in various biological conditions and human diseases, including inflammatory responses and diseases. Previous studies have demonstrated the roles of methyltransferases (MTs) in this context, as well as the potential therapeutic strategies that could target these enzymes [22-26]. Different criteria, including substrates and structural features, have been used to classify MTs. Protein MTs (PMTs) methylate proteins; although histone proteins have been identified as the predominant substrates of PMTs at lysine and arginine residues [27-32], emerging studies suggest that non-histone proteins are also substrates of PMTs [33-36]. DNA MTs (DNMTs) methylate DNA by catalyzing CpG methylation in the promoter regions of many genes responsible for various biological functions and human diseases. Accordingly, dysregulated DNA methylation has been considered a major risk factor for aberrant gene expression and human diseases [23,37-41]. MTs also catalyze the methylation of other biological and chemical molecules, such as natural products, organic compounds, chemical elements, and phospholipids, resulting in the modulation of their biological functions [42-46]. Given the roles of MTs, MTs are thought to play pivotal roles in the cooperation of inflammasomes in inflammatory responses and diseases.

This review discusses the functional relationship and interplay between inflammasomes and MTs and assists in better understanding the cooperative roles of these molecules in inflammatory responses and diseases. This review will also provide insight into the development of anti-inflammatory therapeutics that selectively target inflammasomes and MTs.

\section{Methyltransferases}

MTs comprise a large group of enzymes that transfer methyl groups from methyl donors to their substrates. These enzymes share a general mechanism by which MT binds with S-adenosyl-L-methionine (SAM) (the universal methyl donor for MTs) as well as the target substrate by the different mechanisms, and transfers a methyl group from SAM directly to the target substrate via the classic SN2 reaction. During this process, SAM is converted to S-adenosyl-L-homocysteine (SAH), and the methylated substrates are generated (Figure 1) [47]. MTs are classified using different criteria. Most common way to classify MTs is based on their substrates, such as PMTs, DNMTs, phospholipid MTs, and natural product MTs (Figure 1). MTs are also classified based on their structural features. Here, class I MTs bind SAM using a Rossman fold motif, whereas class II MTs contain a SET (Enhancer-of-zeste and Trithorax) domain for binding SAM. Class III methyltransferases are membrane-associated [48].

\subsection{DNA Methyltransferases}

DNA methylation is a major regulatory process of chromatin structural modification that plays a pivotal role in modulating gene expression during a variety of biological activities. DNA methylation is an essential epigenetic mechanism that functions in combination with other epigenetic changes, such as histone methylation $[49,50]$. DNA methylation occurs only at cytosine residues in eukaryotic cells, and at both cytosine and adenosine residues in bacteria [51]. Although DNA methylation is generally observed at the palindromic CpG sites of both sense and anti-sense DNA strands, reports have described single-stranded DNA methylation at non-CpG sites [51-53]. Correlations of changes in the epigenetic status of DNA with several human diseases, including immune-related diseases, cancers, neurodegenerative diseases, diabetes, and infectious diseases, have been suggested [54-58].

DNMTs catalyze DNA methylation by depositing a methyl group on the $\mathrm{C}-5$ position of a cytosine (Figure 2A). Five human DNMTs with highly conserved catalytic motifs were identified: DNMT1, DNMT2, DNMT3A, DNMT3B, and DNMT3L (Figure 2B). The canonical DNMTs (DNMT1, DNMT3A, and DNMT3B) catalyze DNA methylation, whereas DNMT2 and DNMT3L are non-canonical DNMTs that are not catalytically able to methylate 
DNA [23]. Conserved DNMTs have also been identified in plants with more extensive DNMT gene sequence variations [59], and DNMT4, DNMT5, and DNMT6 have been discovered in fungi and algae $[60,61]$. During DNA replication, DNA methylation can be reversed by active or passive demethylation processes; however, DNMT1, which is also known as a maintenance DNMT, induces hemimethylation at the CpG sites of the DNA strand that lose methylation during DNA replication. In contrast, DNMT3A and DNMT3B do not exert hemimethylation activity at $\mathrm{CPG}$ sites, but instead generate de novo DNA methylation patterns during development and early germ cell differentiation [37].

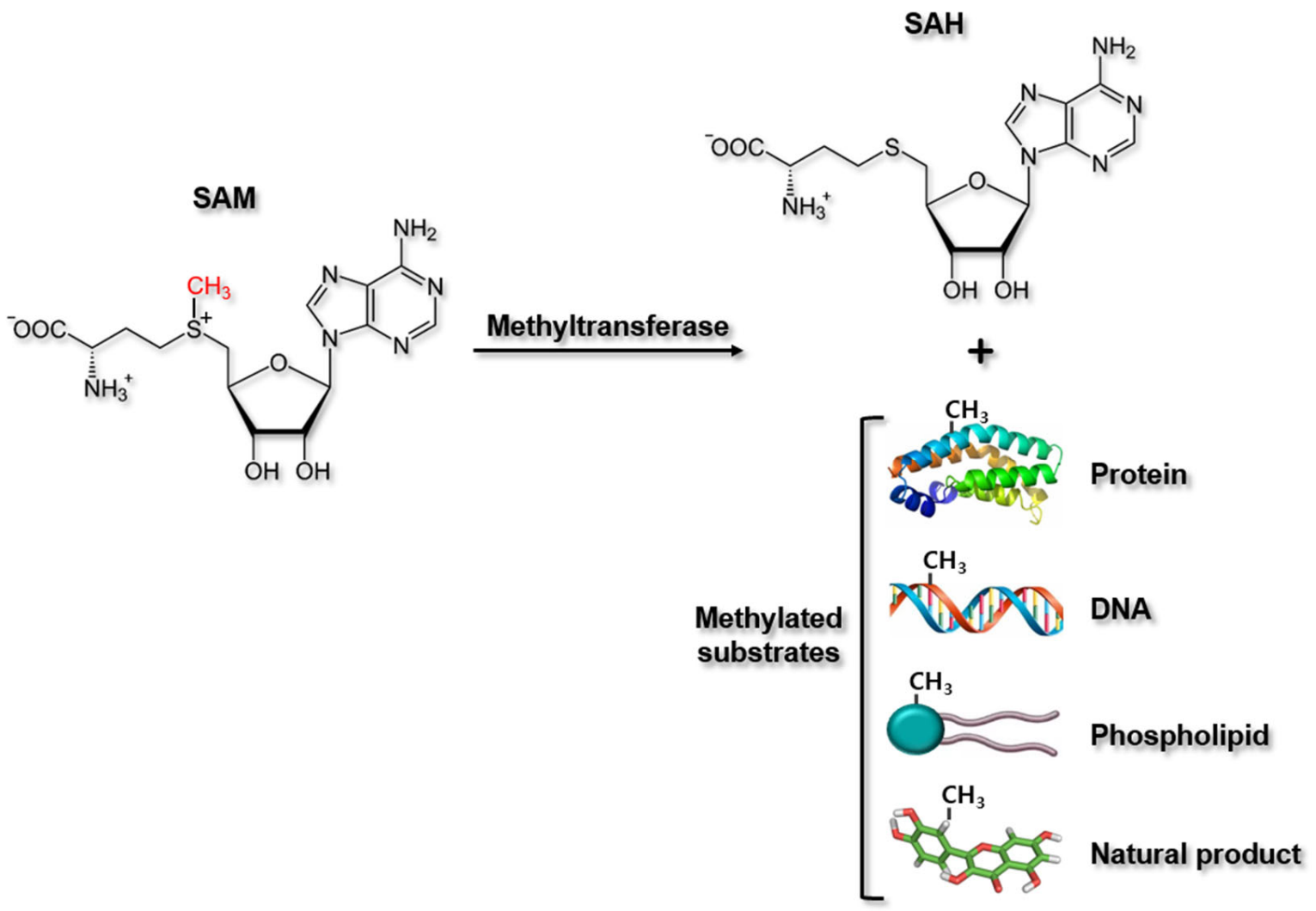

Figure 1. Methylation reaction by methyltransferases. Methyltransferases catalyzes the methylation of cellular molecules, such as proteins, DNA, and phospholipids and some natural products by transferring methyl groups from methyl donor, SAM to their specific substrates, producing methylated substrates and SAH. SAM, S-adenosyl- ${ }_{L}-$ methionine; SAH, S-adenosyl- ${ }_{L}-$ homocysteine.

DNMTs are major epigenetic modulators of the genes expressed in various physiological functions, suggesting that DNMTs could be involved in the pathogenesis of human diseases. Several studies have reported the regulatory roles of DNMTs in human diseases. Interestingly, mutations in DNMT genes have been reported in human diseases. DNMT1 mutation has been identified in neurological diseases [62,63], and DNMT3A mutation was observed in Tatton-Brown-Rahman syndrome, which involves overgrowth and intellectual disability [64]. DNMT3B mutation has been described in several diseases, including immunodeficiency, facial abnormality syndrome, and centromeric instability $[65,66]$. Many reports have described the roles of DNMTs in cancers, as epigenetic changes in DNA methylation patterns comprise one of the most significant molecular alterations associated with tumorigenesis $[67,68]$. Therefore, DNMT mutation repair may be a potential approach to the treatment of various human diseases. The modulation of DNMTs via approved DNMT inhibitors, such as 5-azacytidine and 2'-deoxy-5-azacytidine [69,70], could also be a promising cancer epigenome-targeting strategy for cancer treatment. Further investigations of the functional roles of specific DNMT activities in other human disorders, including inflammatory, metabolic, cardiovascular, and neurological diseases, are urgently needed. 
A

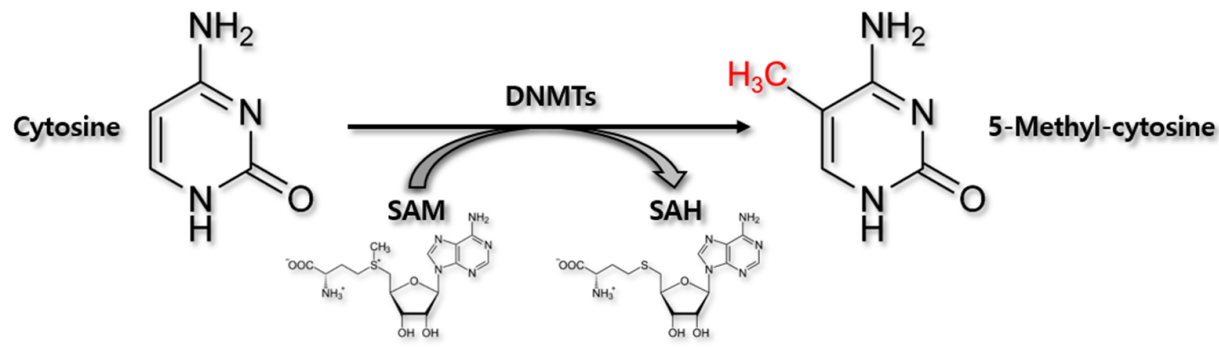

B

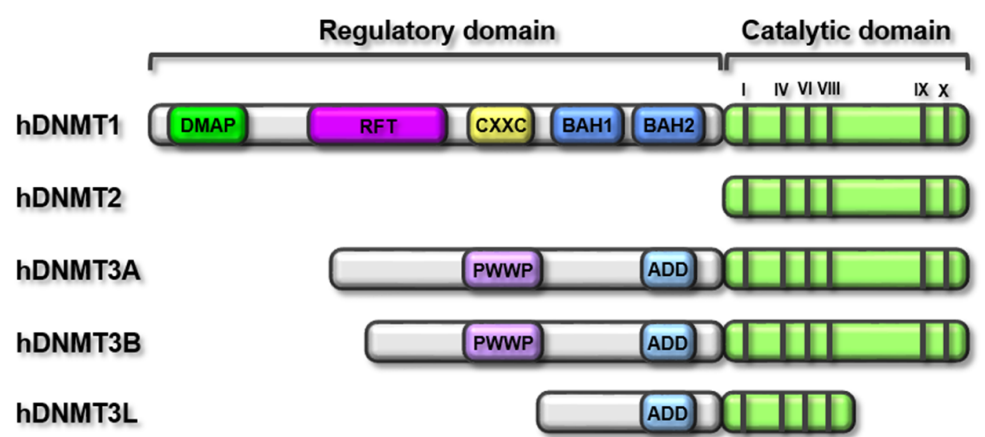

Figure 2. DNMT-mediated methylation reaction and domain structure of human DNMTs. (A) Chemical reaction of DNMTmediated methylation. DNMTs catalyze the methylation at cytosines of $\mathrm{CpG}$ in the gene promoter regions by transferring methyl groups from methyl donor, SAM, producing 5-methyl-cytosine in the gene promoter regions and SAH. (B) Domain structures of human DNMT (hDNMT) family members. hDNMTs consist of five members; hDNMT1 (1616 amino acids), hDNMT2 (391 amino acids), hDNMT3A (912 amino acids), hDNMT3B (853 amino acids), and hDNMT3L (386 amino acids). hDNMTs have two main domains; the regulatory and catalytic domains. The catalytic domain is conserved in all hDNMTs. hDNMT1 is the longest member with DMAP, RFTD, CXXC, and two BAHs in the regulatory domain. hDNMT2 is the smallest member existing only catalytic domain. hDNMT3A and hDNMT3B have PWWP and ADD in the regulatory domain in common, but hDNMT3B is little bit smaller than hDNMT3A. hDNMT3L has only ADD in the regulatory domain with the shorter catalytic domain. Bars in the catalytic domain (I, IV, VI, VIII, IX, and X) represent the catalytic active sites. SAM, S-adenosyl-L-methionine; SAH, S-adenosyl-L-homocysteine; DNMT, DNA methyltransferase; DMAP, DNA methyltransferase-associated protein 1-interacting domain; RFT, replication foci targeting sequence domain; CXXC, CXXC domain; BAH, bromo-adjacent homology domain; PWWP, PWWP domain; ADD, ATRX-DNMT3-DNMT3L domain.

\subsection{Protein Methyltransferases}

PMTs catalyze the methylation of target proteins at the nitrogen-containing side chains of lysine, arginine, and histidine [71,72], but also at the carboxyl group of the prenylated cysteine $[73,74]$ by transferring methyl groups from methyl donors. Although these several amino acids have been identified as methylation residues of target proteins by PMTs, most of the studies have been focusing on the PMTs that methylate lysine and arginine residues. This family of protein-lysine MTs (PKMTs) and protein-arginine MTs (PRMTs) comprises more than 60 members, which mediate the methylation of histone or non-histone substrates on lysine or arginine residues, respectively. PKMTs can transfer up to three methyl groups to the side-chain nitrogen of lysine, thus generating four different states of lysine: non-methyl, mono-methyl, di-methyl, or tri-methyl lysine (Figure 3A). Similarly, PRMTs transfer methyl groups to one or both of the two side-chain nitrogens of arginine, thus producing four different states of arginine: non-methyl, mono-methyl, symmetric di-methyl, or asymmetric di-methyl arginine (Figure 3B). 
A

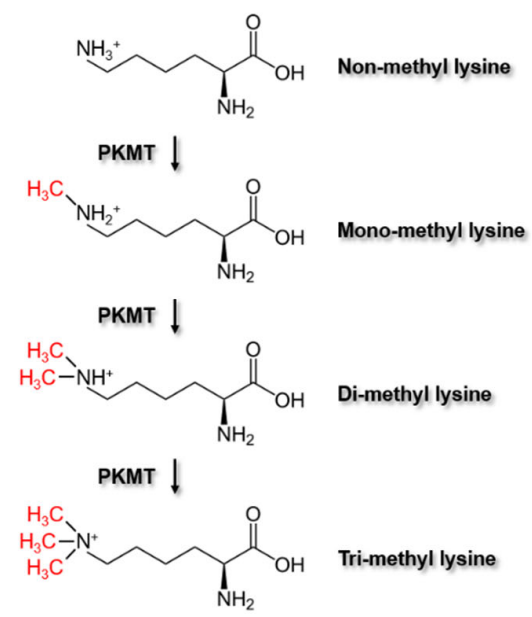

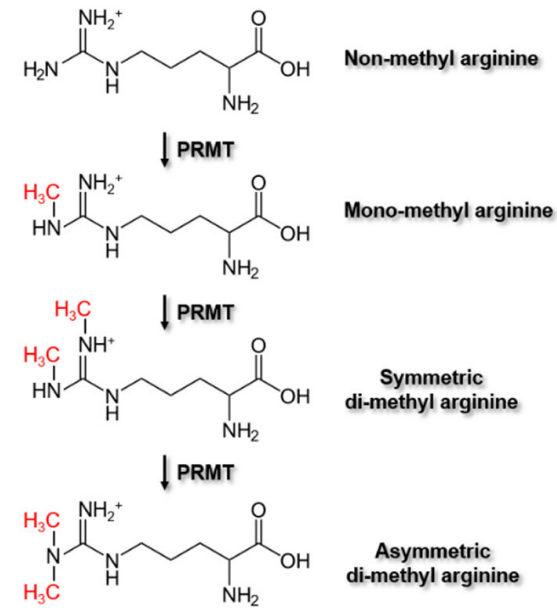

Figure 3. Methylation reactions by PKMT and PRMT. (A) Chemical reactions of PKMT-mediated methylation. PKMTs catalyze the methylation at lysine residue of proteins, producing mono-methyl lysine, di-methyl lysine, and tri-methyl lysine. (B) Chemical reactions of PRMT-mediated methylation. PRMTs catalyze the methylation at arginine residue of proteins, producing mono-methyl arginine and either of symmetric di-methyl arginine or asymmetric di-methyl arginine. PKMT, protein-lysine methyltransferases; PRMT, protein-arginine methyltransferases.

Histones have received a great deal of attention among the known target proteins of MTs [71,75]; as these proteins are essential components of nucleosomes, the regulation of histone methylation plays pivotal roles in gene expression in various biological processes. Moreover, the enzymatic actions of PMTs are thought to be crucial modulators of gene expression, and many studies have demonstrated the active involvement of these PMTs in the pathogenesis of various human diseases, including inflammatory and neurodegenerative diseases, cancers, and other conditions [71,76-82]. Therefore, PKMTs and PRMTs have elicited substantial interest in the fields of medicinal chemistry and drug discovery through attempts to prevent and treat these diseases, and several anticancer drugs that target MTs have already been developed [71].

\section{Inflammasomes}

Inflammasomes are intracellular protein complexes that induce inflammatory responses and consist of the PRRs localized in the cells and the inflammatory effector molecules, such as inflammatory caspases $[7,83,84]$. Intracellular PRRs recognize specific PAMPs and DAMPs and, subsequently, form inflammasomes by interacting with inflammatory effector molecules with or without the help of the bipartite adaptor, apoptosisassociated speck-like protein containing a caspase recruitment domain (ASC), leading to inflammasome activation and inflammasome-induced inflammatory responses $[7,83,84]$. The classification of inflammasomes and the signaling pathways of inflammasome-activated inflammatory responses will be discussed in future studies.

\subsection{Classification and Molecular Architecture of Inflammasomes}

Several different types of inflammasomes can be named after PRRs that promote their assembly. PRRs are distinguished by their structure and assembled into inflammasomes by recognizing different types of PRR-specific PAMPs and DAMPs $[7,85]$. Inflammasomes are classified into two main groups: canonical and non-canonical inflammasomes [7,85]. Canonical inflammasomes include the NLR family, pyrin, and AIM2 inflammasomes, whereas non-canonical inflammasomes include caspase- 11 , caspase- 4 , and caspase- 5 inflammasomes $[7,85]$.

NLR family PRRs are subclassified into five different subfamilies: NLRA, NLRB, NLRC, NLRP, and NLRX [86-88]. To date, 14 NLRP (NLRP1-14) and five NLRC subfamily members (NLRC1-4) have been identified [86-88], but only some subfamily members, 
such as NLRP1, NLRP3, NLRC4, NLRP6, and NLRP9 have been demonstrated to form inflammasomes and activate inflammasome-induced inflammatory responses [7]. NLRP1 is the first NLR family PRR identified and demonstrated to assemble inflammasomes [89]. NLRP1 has the most complex structure comprising an N-terminal PYD, a nucleotidebinding and oligomerization domain (NACHT), leucine-rich repeats (LRRs), a functionalto-find domain (FIIND), and a C-terminal caspase recruitment domain (CARD) (Figure 4A). Unlike human NLRP1, three isoforms of NLRP1 (NLRP1a, NLRP1b, and NLRP1c) have been discovered in mice; however, an N-terminal PYD in human NLRP1 is absent in mouse NLRP1 (Figure 4A). This provides a different mechanism of inflammasome assembly with ASC between human and mouse NLRP1. NLRP3, NLRP6, and NLRP9 have the same domain structure comprising an N-terminal PYD, a NACHT, and C-terminal LRRs (Figure 4A); however, they have different amino acid lengths and LRR numbers. NLRP3, NLRP6, and NLRP9 are 1036, 892, and 991 amino acids in length and have nine, six, and six LRRs, respectively. NLRC4 has a domain structure similar to that of NLRP3, NLRP6, and NLRP9, but has CARD instead of PYD at the N-terminus (Figure 4A). Non-NLR family PRRs include pyrin and AIM2, which form canonical inflammasomes, as well as mouse caspase-11, and human caspase- 4 and -5 , which form non-canonical inflammasomes. Pyrin has a different domain structure compared to that of NLR family PRRs and consists of an N-terminal PYD, a B-box-type zinc finger (Bbox), a coiled-coil (CC), and a C-terminal B30.2, which includes two subdomains, PRY and SPRY (Figure 4A). AIM2 is a member of the IFN-inducible p200 protein family [90], and consists of an N-terminal PYD and a C-terminal hematopoietic IFN-inducible nuclear protein 200 (HIN200) (Figure 4A). Caspase-11 was unexpectedly discovered as an intracellular PRR in mice [91-93], and its homolog was not initially identified in humans. Later, much effort has demonstrated that human caspase-4 and caspase- 5 are the homologs of mouse caspase-11 [94]. Mouse caspase-11, human caspase- 4 , and caspase- 5 have the same domain structure comprising an N-terminal CARD, a p20, and a C-terminal p10 (Figure 4A), but their molecule sizes are different. Mouse caspase-11, human caspase- 4 , and caspase- 5 are 373, 377, and 434 amino acids in length, respectively [10].

The PRRs recognize different types of PAMPs and DAMPs inside the cells in a PRRspecific manner, and are subsequently activated by assembling inflammasomes [7]. Immediately after the sensing of ligands by PRRs, NLR family, pyrin, and AIM2 PRRs assemble canonical inflammasomes via interacting with pro-caspase-1 with or without the help of ASC (Figure 4B) [7,85]. However, mouse caspase-11, human caspase-4, and caspase-5 directly sense their common ligand, intracellular lipopolysaccharide (LPS), which leads to the assembly and activation of non-canonical inflammasomes without the recruitment of pro-caspase-1 and ASC (Figure 4B) [7,79]. The structure and activating ligands of inflammasomes are summarized in Table 1.

\subsection{Inflammasome-Activated Inflammatory Signaling}

As discussed earlier, PRRs recognize the unique types of ligands in a PRR-specific manner (Table 1), and the architecture and mechanism of inflammasome formation are different from one another (Figure 4B). However, inflammasomes share downstream signaling pathways during inflammasome-activated inflammatory responses. Canonical inflammasomes in response to ligands have a molecular architecture that interacts with an inactive form of pro-caspase-1 with or without an adaptor, ASC, leading to the activation of pro-caspase- 1 by autoproteolysis removing CARD and the generation of the active form of caspase- 1 consisting of p20-p10 dimers $[7,79]$. The activated caspase- 1 , in turn, promotes two downstream inflammatory events. Caspase- 1 promotes proteolysis of gasdermin D (GSDMD) at Asp276 residue, producing N-terminal (N-GSDMD) and C-terminal fragments (C-GSDMD). The N-GSDMD then moves to the cell membranes and forms the GSDMD pores in the membranes, leading to GSDMD pore-mediated pyroptosis, an inflammatory form of cell death $[7,79]$. Caspase- 1 also facilitates the maturation and activation of the inactive pro-forms of pro-inflammatory cytokines, such as pro-interleukin (pro-IL)-1 $\beta$ 
and pro-IL-18 by the proteolytic cleavage of $\mathrm{N}$-terminal propeptides and produces the active forms of IL-1 $\beta$ and IL-18, which are secreted from the cells through the GSDMD pores $[7,79]$.

A

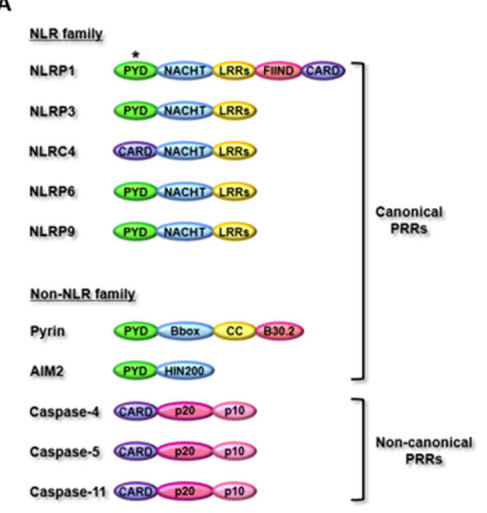

B

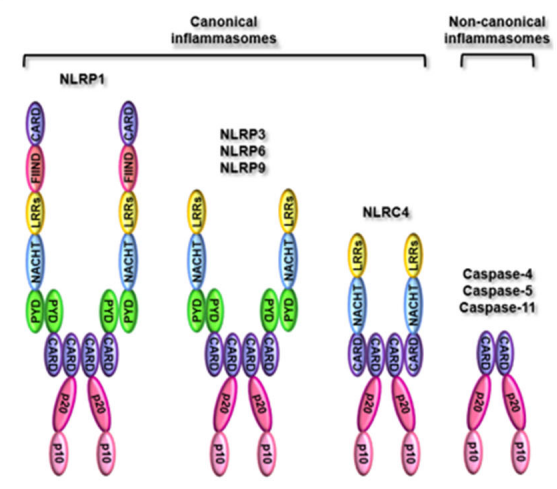

C

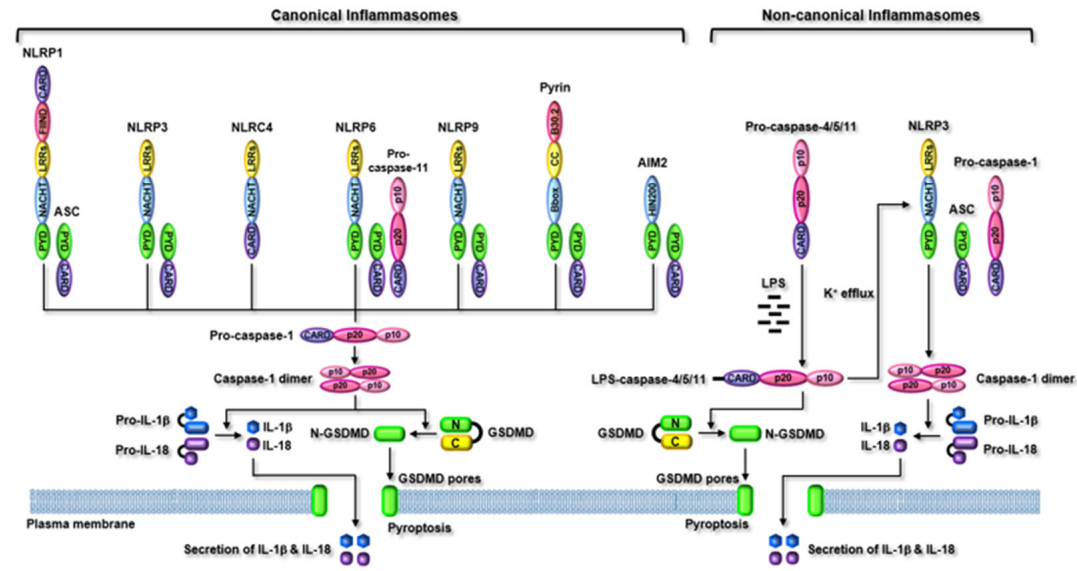

Figure 4. Inflammasome-activated inflammatory signaling (A) the domain structure of PRRs. Inflammasome PRRs are intracellular sensors that include PYD and/or CARD. The PRRs also include NACHT, LRRs, and FIIND in NLR family members. Pyrin includes Bbox, CC, and B30.2 and AIM2 includes HIN200. Caspase-4/5/11 have the same domain structure that includes CARD, p20, and p10. *Absence in mouse NLRP1 isoforms (B) The structure of inflammasomes. Inflammasome PRRs that include a PYD, such as human NLRP1, NLRP3, NLRP6, NLRP9, pyrin, and AIM2 recruit a bipartite adaptor, ASC to mediate CARD-CARD interactions with pro-caspase-1 (ASC-positive scaffolds). While inflammasome PRRs that include CARD instead of PYD, such as mouse NLRP1b and NLRC4 interact directly with pro-caspase-1 without the help of ASC (ASC-negative scaffolds). PRRs of non-canonical inflammasomes, such as mouse caspase-11, human caspase-4, and caspase-5 that include CARD sense directly intracellular LPS and mediate CARD-CARD interaction without the binding of ASC and pro-caspase-1. (C) Inflammasome-activated inflammatory signaling pathways. Inflammasomes are activated in response to PAMPs and DAMPs. The PRRs of canonical inflammasomes directly interact with their specific ligands and respond to various cellular danger signals. The canonical inflammasomes activate caspase- 1 by the proteolytic cleavage of CARD and produce active caspase- 1 dimers. Activated caspase- 1 induces proteolytic cleavage of GSDMD to generate N-GSDMD that then generates GSDMD pores and induces pyroptosis. Activated caspase-1 also induces proteolytic maturation of IL-1 $\beta$ and IL-18 into their active forms, which are secreted through GSDMD pores. PRRs of non-canonical inflammasomes (mouse caspase-11, human caspase-4, and caspase-5) directly interact with intracellular LPS derived from Gram-negative bacteria. The activation of non-canonical inflammasomes also induces proteolytic cleavage of GSDMD, leading to pyroptosis. Non-canonical inflammasomes activate NLRP3 canonical inflammasome by facilitating $\mathrm{K}^{+}$efflux, which subsequently induces proteolytic maturation and secretion of IL-1 $\beta$ and IL-18 through GSDMD pores. PYD, pyrin domain; CARD, caspase recruitment domain; NACHT, nucleotide-binding and oligomerization domain, LRRs, leucine-rich repeats, FIIND, a functional-to-find domain; Bbox, B-box-type zinc finger; CC, coiled-coil; AIM2, absent in melanoma 2; HIN200, hematopoietic interferon-inducible nuclear protein 200; ASC, apoptosis-associated speck-like protein containing a caspase recruitment domain; GSDMD, gasdermin D; LPS, lipopolysaccharide. 
Table 1. Summary of the structure and activating ligands of inflammasomes.

\begin{tabular}{|c|c|c|c|c|}
\hline Categories & PRRs & PRR Domains & $\begin{array}{l}\text { Inflammasome } \\
\text { Components }\end{array}$ & Activating Ligands \\
\hline \multirow{7}{*}{ Canonical } & NLRP1 & $\begin{array}{l}\text { PYD, NACHT, LRRs, } \\
\text { FIIND, CARD }\end{array}$ & $\begin{array}{l}\text { NLRP1, ASC, } \\
\text { pro-caspase-1 }\end{array}$ & Bacillus anthracis toxin \\
\hline & NLRP3 & PYD, NACHT, LRRs & $\begin{array}{l}\text { NLRP3, ASC, } \\
\text { pro-caspase-1 }\end{array}$ & $\begin{array}{c}\text { Bacteria, protozoans, viruses, fungi, ATP, } \\
\text { cell volume fluctuation, cGAMP, } \\
\text { cardiolipin translocation, dsRNA, ER } \\
\text { stress, imiquimod, } \mathrm{K}^{+} \text {efflux, } \\
\text { mitochondrial DNA, mitochondrial ROS, } \\
\text { particulate matter, lysosomal rupture, } \\
\text { RNA-DNA hybrids, nucleic acid hybrids, } \\
\text { pore-generating toxins, hyaluronan, } \\
\text { extracellular } \beta \text {-amyloids, uric acid, alum, } \\
\text { silica }\end{array}$ \\
\hline & NLRC4 & $\begin{array}{l}\text { CARD, NACHT, } \\
\text { LRRs }\end{array}$ & $\begin{array}{c}\text { NLRC4, } \\
\text { pro-caspase-1 }\end{array}$ & $\begin{array}{l}\text { Bacterial needle-like, } \\
\text { bacterial flagellin }\end{array}$ \\
\hline & NLRP6 & PYD, NACHT, LRRs & $\begin{array}{l}\text { NLRP6, ASC, } \\
\text { pro-caspase-11, } \\
\text { pro-caspase-1 }\end{array}$ & $\begin{array}{l}\text { Bile acid-derived taurine, } \\
\text { lipoteichoic acid }\end{array}$ \\
\hline & NLRP9 & PYD, NACHT, LRRs & $\begin{array}{l}\text { NLRP9, ASC, } \\
\text { pro-caspase-1 }\end{array}$ & Short dsRNA \\
\hline & Pyrin & PYD, Bbox, CC, B30.2 & $\begin{array}{c}\text { Pyrin, ASC, } \\
\text { pro-caspase-1 }\end{array}$ & $\begin{array}{l}\text { Bacterial toxin-modified } \\
\text { Rho GTPases }\end{array}$ \\
\hline & AIM2 & PYD, HIN200 & $\begin{array}{c}\text { AIM2, ASC, } \\
\text { pro-caspase-1 }\end{array}$ & dsDNA \\
\hline \multirow{3}{*}{ Non-canonical } & Caspase-4 & CARD, p20, p10 & Caspase-4, LPS & LPS \\
\hline & Caspase-5 & CARD, p20, p10 & Caspase-5, LPS & LPS \\
\hline & Caspase-11 & CARD, p20, p10 & Caspase-11, LPS & LPS \\
\hline
\end{tabular}

Although the PRRs in canonical inflammasomes recognize a variety of ligands and form inflammasomes with pro-caspase- 1 and ASC, the PRRs in non-canonical inflammasomes are activated by very limited types of ligands, and assemble inflammasomes without interacting with pro-caspase-1 and ASC. LPS, an endotoxin of Gram-negative bacterial cell walls, is the first ligand to be identified to activate non-canonical inflammasomes. Mouse caspase-11, human caspase-4, and caspase-5 recognize intracellular LPS internalized by Gram-negative bacteria through direct interaction [7-10,95-97]. Recent studies have identified new ligands, such as lipophosphoglycan (LPG) of Leishmania parasites, the oxidized form of endogenous phospholipids, 1-palmitoyl-2-arachidonoyl-sn-glycero3-phosphorylcholine (oxPAPC), the secreted aspartyl proteinases of Candida albicans to activate non-canonical inflammasomes and inflammatory responses [98-100]. Despite the discovery of these new ligands, the molecular mechanisms by which these ligands activate non-canonical inflammasomes are poorly understood, and most studies demonstrating the non-canonical inflammasome-activated signaling pathways have been mainly focused on LPS.

To trigger the activation of non-canonical inflammasomes, the LPS of Gram-negative bacteria should enter the cells to interact with caspase- $4 / 5 / 11$ and activate non-canonical inflammasomes. Recent studies have demonstrated that extracellular LPS is internalized by bacterial outer membrane vesicles (OMVs), clathrin, caveolin, lipid rafts, and endocytosis with the help of receptors, such as TLR4, the receptor for advanced glycation end-product (RAGE), and syndecan-1 [101-105]. Internalized LPS by endocytosis is still 
in the endosomes and should be released from the endosomes to activate non-canonical inflammasomes. Guanylate-binding proteins (GBPs), members of the GTPase family whose expression is increased by IFN, bind to the LPS-containing endosomal membranes and modify the stability of the membranes. This leads to disruption of the endosomal membranes and LPS release from the endosomes to the cytosol to be exposed to caspase4/5/11 [106-108].

LPS internalized and exposed in the cytosol directly interacts with caspase-4/5/11 through its lipid A moiety to the caspase CARD, and LPS-caspase-4/5/11 complexes form caspase-4/5/11 non-canonical inflammasomes by oligomerization via CARD-CARD interaction, resulting in the activation of non-canonical inflammasomes [7-10,89-91]. The activated non-canonical inflammasomes induce the proteolytic cleavage of GSDMD, leading to GSDMD pore formation in cell membranes and GSDMD pore-mediated pyroptosis [7-10,89-91]. It is still unclear whether non-canonical inflammasomes directly induce caspase- 1 activation and caspase-1-mediated maturation and secretion of IL-1 $\beta$ and IL-18. Recent studies have reported the functional cooperation between non-canonical and canonical inflammasomes during inflammatory responses and demonstrated that non-canonical inflammasomes activate the NLRP3 canonical inflammasome by facilitating $\mathrm{K}^{+}$efflux through P2X7, THIK1/TWIK2, pannexin-1, and GSDMD pores in membranes, which are key and essential determinants of NLRP3 inflammasome activation $[11,109,110]$. This then leads to the proteolytic activation of caspase-1 and the caspase-1-mediated maturation and secretion of IL-1 $\beta$ and IL-18 through GSDMD pores [7-10,89-91]. A schematic summary of inflammasome-activated inflammatory signaling pathways is shown in Figure $4 \mathrm{C}$.

\section{Functional Interplay between Methyltransferases and Inflammasomes}

\subsection{Roles of DNMTs in Inflammasome Functions}

DNMTs catalyze DNA methylation, which plays diverse roles in various biological functions and diseases [111]. Interestingly, recent studies have reported the regulatory roles of DNMT-mediated DNA methylation in inflammasome functions, which provides clues that DNMTs might be critical modulators in inflammasome-mediated inflammatory responses and diseases.

Tang et al. investigated the role of DNMT3B in glycolic acid (GA)-mediated antiinflammatory responses by inhibiting the expression of inflammasome complex genes in human keratinocytes and HaCaT cells. This study reported that while the expression of NLRP3, NLRC4, AIM2, and ASC genes was decreased by GA, GA increased the protein expression and activity of DNMT3B, resulting in the hypermethylation of the promoters of NLRC4 and ASC genes, resulting in the downregulation of the expression of these genes in HaCaT cells [112]. This study suggests that DNMT3B plays an anti-inflammatory role in inflammasome-induced inflammatory responses by inhibiting the expression of inflammasome complex genes, such as NLRC4 and ASC, via hypermethylation of these gene promoters. This study also demonstrates the potential of GA as an anti-inflammatory agent that targets inflammasomes by activating DNMT3B.

Wei et al. reported that NLRP3 inflammasome activation was regulated by DNMT Sss Iinduced methylation in Mycobacterium tuberculosis (Mtb)-infected human monocytes, THP-1 cells. NLRP3 promoter activity was decreased by DNMT Sss I-induced methylation, leading to the downregulation of NLRP3 expression, while the inhibition of NLRP3 promoter methylation by DNMT inhibitor upregulated NLRP3 expression in THP-1 cells [113]. In addition, the promoter of the NLRP3 gene was demethylated by Mtb infection, resulting in the upregulation of NLRP3 genes in THP-1 cells [113]. These results indicate that demethylation of the NLRP3 gene promoter by DNMT Sss I leads to the inhibition of NLRP3 inflammasome activation by decreasing NLRP3 expression, and Mtb infection promotes inflammasome-induced inflammatory responses by suppressing DNMT Sss I-induced methylation of inflammasome gene promoter in human monocytes.

Haldar et al. reported chemotherapeutic-induced DNA damage by global methylation and silencing of DNA damage repair genes in hemorrhagic cystitis, an inflam- 
matory and ulcerative bladder condition. Systemic treatment with chemotherapeutics, cyclophosphamide (CPX), facilitated the accumulation of DNA damage by downregulating the expression of the DNA damage repair gene, Ogg1, and induced subsequent NLRP3 inflammasome-activated pyroptosis of bladder muscle cells in CPX-treated mice [114]. Interestingly, DNMT1 and DNMT3B methylated the promoter of the Ogg1 gene, leading to the Ogg1 silencing and the induction of NLRP3 inflammasome-activated inflammatory responses [114]. Inhibition of Ogg1 silencing by DNA de-methylation suppressed NLRP3 inflammasome activation and NLRP3 inflammasome-induced inflammatory responses, such as pyroptosis and IL-1 $\beta$ secretion in bladder muscle cells [114]. This study is the first to demonstrate the mechanism by which Ogg1 silencing by DNMT-mediated methylation induces NLRP3 inflammasome-activated inflammatory responses in bladder muscle cells and also provides a functional relationship between DNMTs and inflammasomes in systemic chemotherapeutics-induced DNA damage and inflammatory and ulcerative bladder disease, hemorrhagic cystitis.

Huang et al. investigated the DNA methylation levels of NLR family inflammasomes and subsequent inflammatory responses in KD patients with Kawasaki disease (KD). The expression of NLR family PRRs, such as NLRC4 and NLRP12, and pro-inflammatory cytokine, IL-1 $\beta$, was increased, but the methylation levels of the CpG sites of these genes were much lower in the white blood cells of the KD patients than in the normal control subjects [115], indicating that the hypomethylation of the genes of the inflammasome PRRs, NLRC4, and NLRP12 and pro-inflammatory cytokine IL-1 $\beta$ plays a regulatory role in the upregulation of the expression of these genes, resulting in the induction of inflammatory responses and the pathogenesis of KD.

Zhong et al. reported the regulatory role of DNMT1 in microRNA (miR) expression and inflammasome activation in atherosclerosis in ApoE knockout (KO) mice. DNMT1 hypermethylated the promoter of miR-145, which decreased plaque formation and consequently reduced the expression of miR-145 in vessels, leading to the activation of NLRP3 inflammasome and subsequent inflammatory responses, including the production and secretion of IL-1 $\beta$ in ApoE KO mice [116]. This study provides insights linking DNA methylation and inflammasome activation in atherosclerosis and also provides the potential for developing new therapeutics by targeting DNMT and inflammasomes for the treatment of atherosclerosis as well as other inflammatory diseases.

Sun et al. explored the functional relationship between DNA methylation and inflammasome activation in osteoarthritis (OA) using human osteoarthritic cells and OA patients. The C-terminal-binding proteins (CtBPs) that are highly expressed in OA promote the activation of the NLRP3 inflammasome and downstream inflammatory signaling, such as caspase- 1 activation and IL-1 $\beta$ maturation in osteoarthritic cells and OA patients [117]. Interestingly, the expression levels of DNMT1 and DNMT3A were lowered in OA patients, and the knockdown of DNMT1 and DNMT3A resulted in the hypomethylation of CtBP promoters, leading to CtBP overexpression and NLRP3 inflammasome activation in OA patients [117]. These results indicate that DNMTs play an inhibitory role in inflammasome activation and inflammatory responses, whilst also providing insight into the functional relationship between DNMTs and inflammasomes in the pathogenesis of OA.

Zhai et al. reported on the role of $O^{6}$-methylguanine-DNA methyltransferase (MGMT), an enzyme that repairs drug-induced DNA damage in acquired drug resistance by modulating inflammasome activation in melanoma cell lines. Melanoma cells treated with temozolomide (TMZ) over two months upregulated the expression of MGMT and became TMZ resistant [118]. Furthermore, TMZ-resistant melanoma cells showed increased expression of NLRP1 and activation of the NLRP1 inflammasome, leading to the maturation and secretion of IL-1 $\beta$ [118]. Although inflammation has been demonstrated to be associated with drug resistance in various cancers in previous studies, this study provides a critical clue for the functional interplay between DNMT and inflammasome in the development of acquired drug resistance in cancers. It also provides invaluable insight into the develop- 
ment of anti-cancer therapeutics against drug-resistant cancers via selective targeting of DNMTs or inflammasomes.

Abplanalp et al. demonstrated the functional cooperation between DNMT mutations and inflammasome activation in the alteration of immune cells in chronic heart failure. Monocytes derived from chronic heart failure patients carrying DNMT3A mutations revealed a significantly increased expression of inflammasome genes, such as NLRP3 and IL-1 $\beta$, compared with the monocytes isolated from chronic heart failure patients with no DNMT3A mutations [119]. DNMT3A silencing in monocytes also increased the secretion of pro-inflammatory cytokines [119]. Interestingly, monocytes of DNMT3A mutation carriers showed increased expression of T-cell-stimulating molecules and the changes in signatures of T-cell subsets, such as $\mathrm{T}_{\mathrm{H}} 1, \mathrm{~T}_{\mathrm{H}} 2, \mathrm{~T}_{\mathrm{H}} 17, \mathrm{CD} 4+$ memory, $\mathrm{CD} 8$ cytotoxic, and regulatory $\mathrm{T}$ cells [119]. These results suggest that the monocytes and T-cells with clonal hematopoiesisdriver mutations in DNMT3A play a cooperative role in inducing inflammatory responses in chronic heart failure by promoting the production of a highly inflamed transcriptome and inflammasome activation that may lead to the exacerbation of chronic heart failure.

Yu et al. reported ethanol-induced inflammasome activation and inflammatory responses by modulating the methylation of DNA encoding fat mass and obesity-associated protein (FTO), the $\mathrm{m}^{6} \mathrm{~A}$ demethylase in alcohol-induced kidney injury. Ethanol administration induces NLRP3 inflammasome activation, the production of pro-inflammatory cytokines, and renal inflammation in the alcoholic kidneys of mice and human kidney tubular epithelial HK2 cells [120]. Interestingly, ethanol administration highly methylated the DNA encoding FTO and consequently downregulated its expression in the alcoholic kidneys of mice and HK2 cells [120]. Moreover, inhibition of DNMTs, such as DNMT1, DNMT3A, and DNMT3B by their specific inhibitor, 5-azacytidine, recovered FTO expression and alcohol-induced kidney injury in mice and HK2 cells, indicating that alcohol promotes FTO methylation through DNMTs [120]. Moreover, FTO promoted PPAR- $\alpha \mathrm{m}^{6} \mathrm{~A}$ methylation and PPAR $\alpha$-induced NLRP3 inflammasome activation in the alcoholic kidneys of mice and HK2 cells [120]. This study suggests that alcohol induces inflammasome activation and renal inflammation by increasing the expression of DNMTs and inducing the subsequent epigenetic modification of FTO and PPAR- $\alpha$ in the kidney. This study also provides a functional association between DNMTs and inflammasomes in alcoholic kidney disease. The regulatory roles of DNMTs in inflammasome function during inflammatory responses and diseases discussed in this study are described in Figure 5 and summarized in Table 2.

\subsection{Roles of Histone MTs in Inflammasome Functions}

Histone proteins have been demonstrated as the major substrates of PMTs [27-29]. Histone methylation can be generated at various sites in histone proteins primarily at lysine and arginine residues [121]. Histone methylation can be governed by various positive and negative modulators, resulting in activation or repression of gene transcription [121]. Histone methylation is essential for ensuring the subsequent coordinated transcriptional regulation of gene networks that are critical for normal animal development and almost all biological events-inappropriate histone methylation can cause multiple human diseases [121-123]. Recently emerging studies have demonstrated the regulatory roles of histone MTs in inflammasome activation, suggesting that, similar to DNMTs, histone MTs also cooperate with inflammasomes and play regulatory roles in inflammasome-induced inflammatory responses and diseases.

The nuclear receptor-binding SET domain protein 1 (NSD1) is a lysine methyltransferase that preferentially methylates histone 3 (H3) and $\mathrm{H} 4$ on lysine 36 residue (K36) and K20, respectively and alters transcription by interacting with the protein NSD1interacting zinc finger protein 1 (NIZP1) [124-126]. Sakhon et al. demonstrated the regulatory role of NSD1 in the activation of caspase-1, a downstream effector of inflammasome activation and caspase-1-mediated inflammatory responses during Listeria monocytogenes listeriolysin O (LLO) stimulation of macrophages. LLO induced NLRP3 inflam- 
masome activation and IL-1 $\beta$ secretion and upregulated NSD1 expression in mouse bone marrow-derived macrophages (BMDMs) [127]. Unexpectedly, NSD1 inhibited NLRP3 inflammasome-induced maturation and secretion of IL-1 $\beta$ and IL-18, but neither restricted NLRP3 inflammasome activation at the chromatin level nor influenced NLRP3 gene expression in the LLO-stimulated BMDMs [127]. Interestingly, NSD1 inhibition induced caspase- 1 activation and IL-1 $\beta$ secretion in the LLO-stimulated BMDMs [127]. This study suggests a functional association between histone MT, NSD1, and inflammasome signaling during bacterial infection-induced inflammatory responses and further provides the therapeutic potential of infectious diseases by selectively targeting or modulating histone MTs and inflammasome signaling pathways during inflammasome-mediated inflammatory responses.

A

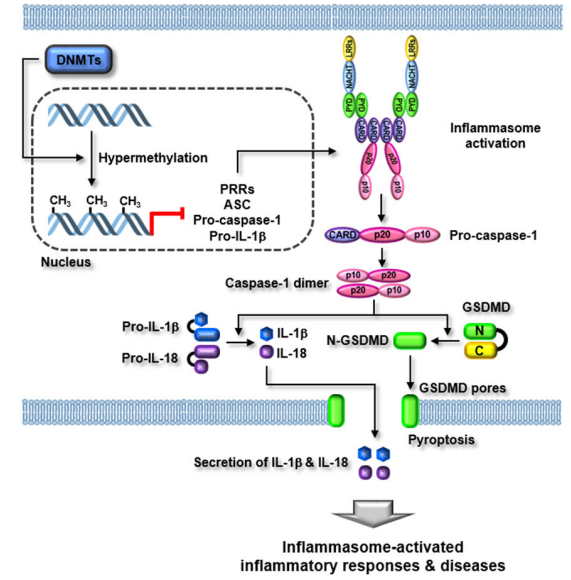

B

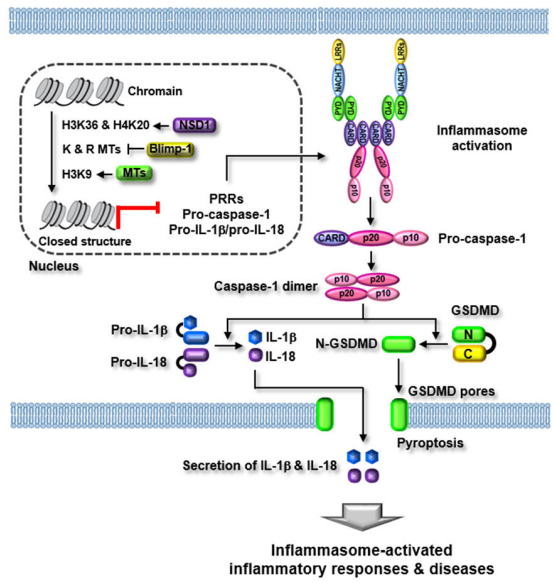

Figure 5. Regulatory role of MTs in inflammasome activation in inflammatory responses and diseases. (A) DNMTs induce hypermethylation in the promoter regions or genes of inflammasome components, such as PRRs, ASC, pro-caspase-1, and pro-inflammatory cytokines, and consequently inhibit the transcriptional expression of these genes and inflammasome activation. As a result, the caspase-1-mediated GSDMD pore formation and pro-inflammatory cytokine secretion are subsequently inhibited, resulting in the suppression of inflammasome-activated inflammatory responses and diseases. (B) NSD1, Blimp-1, and histone MTs directly or indirectly induce the hypermethylation or hypomethylation of histone proteins at lysine $(\mathrm{K})$ and arginine $(\mathrm{R})$ residues and close the chromatin structure, leading to the inhibition of the transcriptional expression of inflammasome component genes and inflammasome activation. As a result, the caspase-1-mediated GSDMD pore formation and pro-inflammatory cytokine secretion are subsequently suppressed, resulting in the amelioration of inflammasome-activated inflammatory responses and diseases. MTs, methyltransferases; DNMTs, DNA methyltransferases, ASC, apoptosis-associated speck-like protein containing a caspase recruitment domain; GSDMD, gasdermin D.

B lymphocyte-induced maturation protein-1 (Blimp-1) is a DNA-binding zinc fingercontaining transcriptional repressor that induces promoter silencing by recruiting histone lysine MTs, histone arginine MTs, histone deacetylase, and co-repressors [128-130]. Shi et al. reported the functional crosstalk between the TLR4-Blimp-1 axis and NLRP12 inflammasome in inflammatory responses in dendritic cells and BMDMs, as well as an experimental mouse colitis model. Dextran sodium sulfate (DSS) stimulation induced caspase- 1 activation and IL-1 $\beta$ secretion, and inhibition of NLRP12 increased IL- $1 \beta$ secretion in dendritic DC2.4 cells and BMDMs [131]. DSS-induced overexpression of Blimp-1 resulted in the downregulation of NLRP12 expression in DSS-stimulated DC2.4 cells and BMDMs [131]. Moreover, TLR4 was implicated in Blimp-1 upregulation, which subsequently leads to Blimp-1-mediated NLRP12 downregulation and IL-1 $\beta$ secretion in DSSinduced colitis mice [131]. These results indicate that Blimp-1 recruiting and modulating histone MT functions induces inflammatory responses and colitis by inhibiting NLRP12 
inflammasome activation in dendritic cells and macrophages. This also suggests evidence of the negative correlation between histone MTs and inflammasomes during inflammatory responses and diseases.

Papale et al. also demonstrated a functional correlation between the NLRP12 inflammasome and Blimp-1 in allergic contact dermatitis in human skin. Contact allergens, such as p-phenylenediamine (PPD) and 2,4-dinitrochlorobenzene (DNCB), increased the expression of Blimp-1 and IL-18, which are critical players in allergic diseases [132], but decrease NLRP12 expression in human keratinocytes, NCTC 2544 cells [133]. This result is in accordance with the previous study by Shi et al. [131], which showed that NLRP12 and Blimp-1 expression is inversely correlated, further demonstrating that Blimp-1 silencing increased NLRP12 expression and reduced contact allergen-induced IL-18 production in NCTC 2544 cells [133]. These results indicate that contact allergens induced allergic contact dermatitis by producing IL-18 through differentially modulating the expression of NLRP12 and Blimp-1 in keratinocytes. It also suggests that histone MTs recruited by Blimp- 1 to NLRP12 promoter may play a pivotal role in the inhibition of NLRP12 inflammasome activation and the production of allergic IL-18 in the skin. Furthermore, the study by Shi et al. study [131] provides insight into the development of potential therapeutics for allergic diseases by selectively modulating NLRP12 inflammasome and Blimp-1 activities. Although Blimp-1 suppressed the transcription of inflammasome components by inhibiting the recruitment of histone arginine MTs in these two studies, these studies did not provide the direct evidence that histone arginine MTs are critical players by actively participating in the transcriptional control of inflammasome components, which demands the further studies demonstrating the regulatory roles of histone arginine as well as lysine MTs in transcriptional regulation of inflammasome genes.

IFN- $\gamma$-inducible protein 16 (IFI16) is an intracellular sensor of foreign DNA that induces inflammasome-mediated inflammatory responses [134-136]. A previous study demonstrated that IFI16 inhibition resulted in the disruption of Kaposi's sarcoma-associated herpesvirus (KSHV) latency and induced lytic transcript [137], but the underlying molecular mechanism is unknown. Roy et al. investigated the mechanism of IFI16-mediated transcriptional regulation of the KSHV lytic pathway. The study reported the regulatory role of two different histone MTs that methylate H3K9, SUV39H1, and GLP by epigenetic modification of KSHV genomes in IFI16-induced inflammasome responses during host defense immunity. IFI16 interacts with SUV39H1 and GLP to generate the IFI16/SUV39H1/GLP complex, and the complex is recruited to the KSHV genome, leading to the methylation of H3K9 during viral infection and latency [138]. The methylated H3K9 serves as a docking site for HP1 $\alpha$, a heterochromatin-inducing factor, resulting in IFI16-mediated H3K9-trimethylation and silencing of KSHV lytic genes [138]. This study suggests that IFI16 cooperation with histone MTs is one of the critical mechanisms by which IFI16 regulates host innate immunity by sensing foreign DNA and inducing epigenetic modification during viral infection. However, this study did not show direct evidence of how the cooperation between IFI16 and histone MTs regulates the inflammasome signaling pathway in host cells against viral infection, which raises the demand for future studies in this regard. The regulatory roles of histone MTs in inflammasome function during inflammatory responses and diseases discussed in this study are described in Figure 5 and summarized in Table 2. 
Table 2. Summary of functional cooperation between MTs and inflammasomes.

\begin{tabular}{|c|c|c|c|}
\hline Types & Study Results & Exp. Models & Ref. \\
\hline & $\begin{array}{l}\text { - GA decreased expression of NLRP3, NLRC4, AIM2, and } \\
\text { ASC genes in HaCaT cells. } \\
\text { GA increased protein expression and activity of } \\
\text { DNMT3B in HaCaT cells. } \\
\text { - GA induced hypermethylation of NLRC4 and ASC gene } \\
\text { promoters in HaCaT cells. }\end{array}$ & Human keratinocytes (HaCaT cells) & [112] \\
\hline & $\begin{array}{l}\text { - Mtb infection induced inflammatory responses by } \\
\text { increasing NLRP3 gene expression by demethylation of } \\
\text { NLRP3 gene promoter in THP-1 cells. } \\
\text { NLRP3 promoter activity was decreased by the DNMT } \\
\text { Sss I-induced methylation, leading to downregulation of } \\
\text { NLRP3 expression in THP-1 cells. } \\
\text { Inhibition of NLRP3 promoter methylation by DNMT } \\
\text { inhibitor upregulated NLRP3 expression in THP-1 cells. }\end{array}$ & $\begin{array}{l}\text { Human monocytes } \\
\text { (HP-1 cells) }\end{array}$ & [113] \\
\hline \multirow{4}{*}{ DNMTs } & $\begin{array}{l}\text { CPX facilitated accumulation of DNA damage by } \\
\text { downregulating the Ogg1 gene expression and induced } \\
\text { subsequent NLRP3 inflammasome-activated pyroptosis } \\
\text { of the bladder muscle cells in the CPX-treated mice. } \\
\text { DNMT1 and DNMT3B methylated Ogg1 gene promoter } \\
\text { and promoted Ogg1 gene silencing, resulting in } \\
\text { induction of NLRP3 inflammasome-activated } \\
\text { inflammatory responses in the bladder muscle cells in } \\
\text { the CPX-treated mice. } \\
\text { Inhibition of Ogg1 silencing by DNA de-methylation } \\
\text { suppressed NLRP3 inflammasome activation and } \\
\text { NLRP3 inflammasome-induced inflammatory responses } \\
\text { (pyroptosis and IL-1 } \beta \text { secretion) in bladder muscle cells. }\end{array}$ & $\begin{array}{c}\text { CPX-treated mice } \\
\text { Mouse bladder muscle cells }\end{array}$ & [114] \\
\hline & $\begin{array}{l}\text { - Expression of NLRC4, NLRP12, and IL-1 } \beta \text { was increased } \\
\text { in KD patients. } \\
\text { NLRC4, NLRP12, and IL-1 } \beta \text { genes were } \\
\text { hypomethylated in KD patients. }\end{array}$ & White blood cells from KD patients & [115] \\
\hline & $\begin{array}{l}\text { - } \quad \text { miR-145 decreased plaque formation in vessels of ApoE } \\
\text { KO mice. } \\
\text { DNMT1 induced hypermethylation of miR-145 } \\
\text { promoter and decreased miR-145 expression in vessels } \\
\text { of ApoE KO mice. } \\
\text { DNMT1-mediated downregulation of miR-145 } \\
\text { expression induced NLRP3 inflammasome activation } \\
\text { and IL-1 } \beta \text { secretion in ApoE KO mice. }\end{array}$ & ApoE KO mice & [116] \\
\hline & $\begin{array}{l}\text { - CtBPs are highly expressed in OA. } \\
\text { CtBPs promoted activation of NLRP3 inflammasome, } \\
\text { caspase-1, and IL-1 } \beta \text { in osteoarthritic cells and OA } \\
\text { patients. } \\
\text { Expression levels of DNMT1 and DNMT3A were } \\
\text { lowered in OA patients. } \\
\text { Knockdown of DNMT1 and DNMT3A resulted in } \\
\text { hypomethylation of CtBP promoters, leading to CtBP } \\
\text { overexpression and NLRP3 inflammasome activation in } \\
\text { OA patients. }\end{array}$ & $\begin{array}{c}\text { OA patients } \\
\text { Human osteoarthritic cells }\end{array}$ & [117] \\
\hline
\end{tabular}


Table 2. Cont.

\begin{tabular}{|c|c|c|c|}
\hline Types & Study Results & Exp. Models & Ref. \\
\hline & $\begin{array}{l}\text { - Melanoma cells treated with TMZ over two months } \\
\text { upregulated MGMT expression and became TMZ } \\
\text { resistant. } \\
\text { TMZ-resistant melanoma cells increased NLRP1 } \\
\text { expression and induced NLRP1 inflammasome } \\
\text { activation, leading to the maturation and secretion of } \\
\text { IL-1 } \beta \text {. }\end{array}$ & $\begin{array}{l}\text { Human melanoma cells }(1205 \mathrm{Lu} \\
\text { and HS294T cells) }\end{array}$ & [118] \\
\hline & $\begin{array}{l}\text { Monocytes derived from chronic heart failure patients } \\
\text { carrying DNMT3A mutations revealed a significantly } \\
\text { increased expression of inflammasome genes, such as } \\
\text { NLRP3 and IL-1 } \beta \text { compared with monocytes isolated } \\
\text { from chronic heart failure patients with no DNMT3A } \\
\text { mutations. } \\
\text { DNMT3A silencing in monocytes also increased } \\
\text { secretion of pro-inflammatory cytokines. } \\
\text { Monocytes of DNMT3A mutation carriers showed } \\
\text { increased expression of T-cell-stimulating molecules and } \\
\text { changes in T-cell signatures. }\end{array}$ & $\begin{array}{l}\text { Monocytes and T-cells from chronic } \\
\text { heart failure patients }\end{array}$ & [119] \\
\hline & $\begin{array}{l}\text { Ethanol administration induced NLRP3 inflammasome } \\
\text { activation, pro-inflammatory cytokine production, and } \\
\text { renal inflammation in alcoholic kidneys of mice and } \\
\text { HK2 cells. } \\
\text { Ethanol administration highly methylated FTO DNA } \\
\text { and downregulated FTO expression in alcoholic kidneys } \\
\text { of mice and HK2 cells. } \\
\text { Inhibition of DNMT1, DNMT3A, and DNMT3B } \\
\text { recovered FTO expression and alcohol-induced kidney } \\
\text { injury in mice and HK2 cells. } \\
\text { FTO promoted PPAR- } \alpha \mathrm{m}^{6} \text { A methylation and } \\
\text { PPAR- } \alpha \text {-induced NLRP3 inflammasome activation in } \\
\text { alcoholic kidneys of mice and HK2 cells. }\end{array}$ & $\begin{array}{c}\text { Alcohol-induced kidney injury mice } \\
\text { Human kidney tubular epithelial } \\
\text { cells (HK2 cells) }\end{array}$ & [120] \\
\hline $\begin{array}{l}\text { Histone } \\
\text { MTs }\end{array}$ & $\begin{array}{l}\text { - } \quad \text { LLO induced NLRP3 inflammasome activation and } \\
\text { IL-1 } \beta \text { secretion and upregulated NSD1 expression in } \\
\text { mouse BMDMs. } \\
\text { NSD1 inhibited NLRP3 inflammasome-induced } \\
\text { maturation and secretion of IL-1 } \beta \text { and IL-18 in } \\
\text { LLO-stimulated BMDMs. } \\
\text { NSD1 neither restricted NLRP3 inflammasome } \\
\text { activation at the chromatin level nor influenced NLRP3 } \\
\text { gene expression in LLO-stimulated BMDMs. } \\
\text { NSD1 inhibition induced caspase-1 activation and IL-1 } \beta \\
\text { secretion in LLO-stimulated BMDMs. }\end{array}$ & Mouse BMDMs & [127] \\
\hline
\end{tabular}


Table 2. Cont.

\begin{tabular}{|c|c|c|c|}
\hline Types & Study Results & Exp. Models & Ref. \\
\hline & $\begin{array}{l}\text { - } \\
\text { - } \quad \text { InS stimulation induced caspase-1 activation and IL-1 } \beta \\
\text { DSS-stimulated dendritic DC2.4 cells and BMDMs. } \\
\text { - } \quad \text { DSS-induced overexpression of Blimp-1 resulted in } \\
\text { downregulation of NLRP12 expression in } \\
\text { DSS-stimulated DC2.4 cells and BMDMs. } \\
\text { - TLR4 expression upregulated Blimp-1 expression and } \\
\text { leads to Blimp-1-mediated NLRP12 downregulation and } \\
\text { IL-1 } \beta \text { secretion in DSS-induced colitis mice. }\end{array}$ & $\begin{array}{c}\text { DSS-treated mice } \\
\text { Mouse dendritic cells (DC2.4) and } \\
\text { BMDMs }\end{array}$ & [131] \\
\hline & $\begin{array}{l}\text { - Contact allergens increased expression of Blimp-1 and } \\
\text { IL-18 and decreased NLRP12 expression in NCTC } 2544 \\
\text { cells. } \\
\text { Blimp-1 silencing increased NLRP12 expression and } \\
\text { reduced contact allergen-induced IL-18 production in } \\
\text { NCTC } 2544 \text { cells. }\end{array}$ & $\begin{array}{l}\text { Human keratinocytes } \\
\text { (NCTC } 2544 \text { cells) }\end{array}$ & [133] \\
\hline & $\begin{array}{l}\text { - IFI16 interacted with SUV39H1 and GLP generating the } \\
\text { IFI16/SUV39H1/GLP complex. } \\
\text { IFI16/SUV39H1/GLP complex was recruited to KSHV } \\
\text { genome and induced H3K9 methylation during viral } \\
\text { infection and latency. } \\
\text { - The methylated H3K9 served as a docking site for HP1 } \alpha \text {, } \\
\text { resulting in IFI16-mediated epigenetic modification and } \\
\text { silencing of KSHV lytic genes. }\end{array}$ & $\begin{array}{l}\text { KSHV-positive PEL cells (BCBL-1 } \\
\text { and BC-3 cells) } \\
\text { KSHV-negative BJAB cells }\end{array}$ & [138] \\
\hline
\end{tabular}

\section{Conclusions}

Although inflammation is essential for protecting the body from invading pathogens and cellular danger signals, chronic inflammation has been considered as a major risk factor and secret killer for a variety of human diseases. For this reason, much effort has been made to elucidate the mechanisms of inflammatory responses and development of therapeutics against human inflammatory diseases. Between the two steps of inflammatory responses, triggering has been regarded as the critical step in activating and further boosting the inflammatory responses by activating intracellular inflammatory protein complexes, inflammasomes, and subsequent inflammasome-induced effector responses, such as pyroptosis and release of pro-inflammatory cytokines. This has led to extensive studies demonstrating the regulatory roles of inflammasomes in inflammatory responses and diseases. However, despite efforts over the last several decades, it is still under active investigation how inflammasomes are regulated and cooperate with other molecules during inflammatory responses.

The methylation of cellular molecules, such as DNA and proteins, is critical for regulating gene expression and protein activity in various cellular biological functions. In addition, the methylation of non-histone proteins, lipids, and other cellular molecules plays a pivotal role in modulating various cellular functions. Many research groups have therefore investigated the regulatory roles of methyltransferases in multiple physiological and pathological conditions, and have demonstrated the active involvement of DNMTs and PMTs in various biological processes and human diseases by the epigenetic modification of gene promoters and proteins, especially histones. Moreover, studies have attempted to selectively target methyltransferases to develop effective therapeutics for human diseases.

The important role of MT methylation in the regulation of inflammasome functions has gained attention due to the functional cooperation of MTs with inflammasomes in 
inflammatory responses. This understanding is crucial to the development of novel antiinflammatory therapeutics by targeting MTs and inflammasomes. Given the evidence discussed in this study, various DNMTs and PMTs, especially histone MTs, play critical roles in regulating inflammasome functions and inflammasome-activated downstream effects in inflammatory responses and diseases. However, despite these successful studies, the regulatory roles of MTs in inflammasome functions have been demonstrated, focusing only on several types of DNMTs and histone MTs, and the functional cooperation between other types of MTs, such as MTs of non-histone proteins, lipids, and other cellular molecules, is poorly understood. In addition, most of the studies have mainly focused on NLRP3 inflammasome and other NLR family inflammasomes-further studies are required to investigate the regulatory role of MTs in the functioning of other types of inflammasomes, especially non-canonical inflammasomes that were recently discovered and demonstrated to play a crucial role in infection-mediated inflammatory responses and diseases.

In conclusion, MTs are critical players in inflammasome functions by the epigenetic modification of DNA and proteins in inflammatory responses and diseases. The selective modulation of MT and inflammasome functions could be a potential strategy to develop novel anti-inflammatory therapeutics to prevent and treat inflammatory and inflammationmediated diseases.

Author Contributions: Y.-S.Y. conducted the literature search, designed the manuscript structure, and wrote the manuscript. The author has read and agreed to the published version of the manuscript.

Funding: This research was funded by a National Research Foundation of Korea (NRF) grant funded by the Korean government (MSIT) (NRF-2020R1F1A1074415).

Institutional Review Board Statement: Not applicable.

Informed Consent Statement: Not applicable.

Data Availability Statement: Not applicable.

Conflicts of Interest: The author declares no conflict of interest.

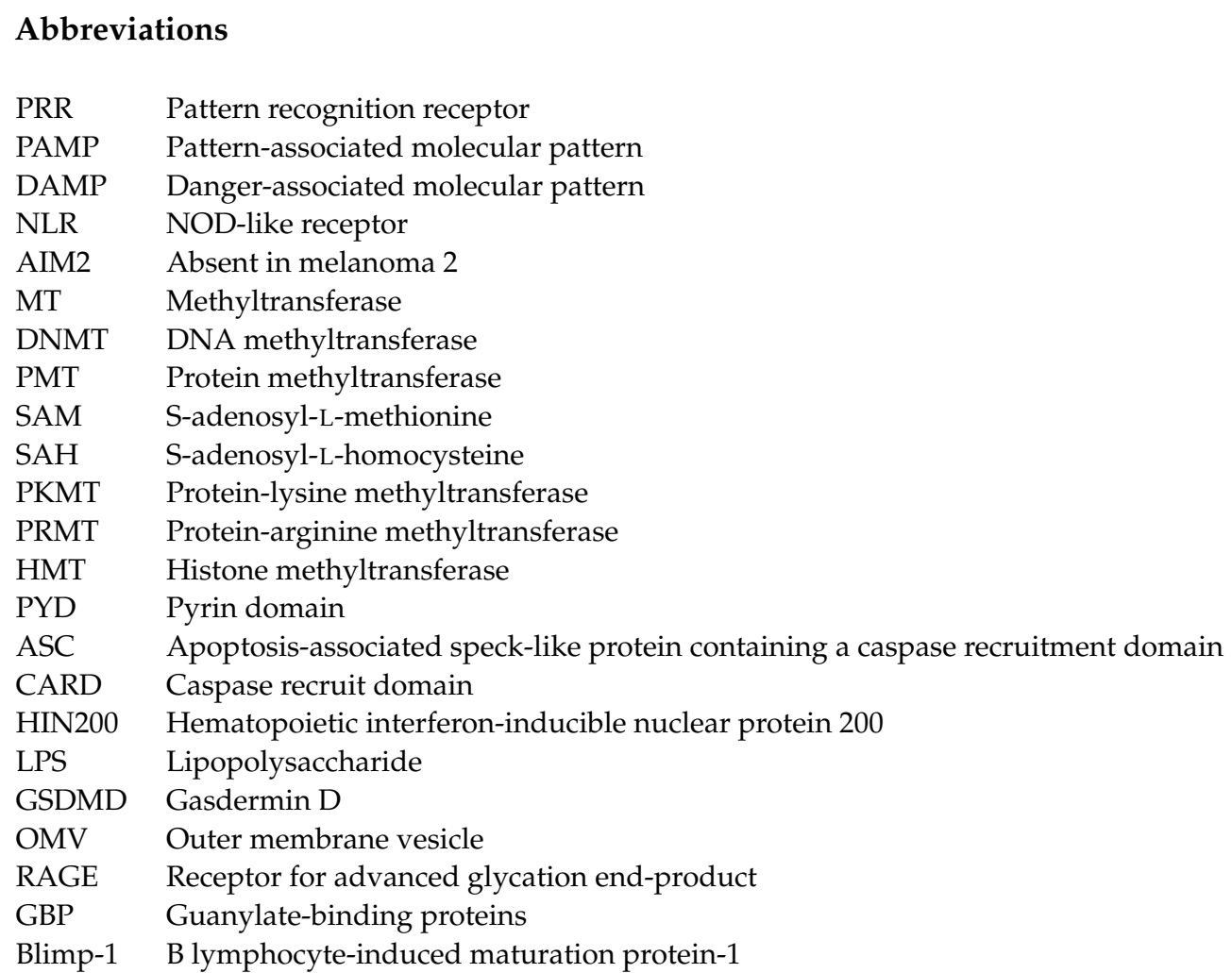




\section{References}

1. Janeway, C.A., Jr.; Medzhitov, R. Innate immune recognition. Annu. Rev. Immunol. 2002, 20, 197-216. [CrossRef] [PubMed]

2. Takeuchi, O.; Akira, S. Pattern recognition receptors and inflammation. Cell 2010, 140, 805-820. [CrossRef] [PubMed]

3. Yi, Y.S.; Son, Y.J.; Ryou, C.; Sung, G.H.; Kim, J.H.; Cho, J.Y. Functional roles of Syk in macrophage-mediated inflammatory responses. Mediat. Inflamm. 2014, 2014, 270302. [CrossRef] [PubMed]

4. Yang, Y.; Kim, S.C.; Yu, T.; Yi, Y.S.; Rhee, M.H.; Sung, G.H.; Yoo, B.C.; Cho, J.Y. Functional roles of p38 mitogen-activated protein kinase in macrophage-mediated inflammatory responses. Mediat. Inflamm. 2014, 2014, 352371. [CrossRef]

5. Yu, T.; Yi, Y.S.; Yang, Y.; Oh, J.; Jeong, D.; Cho, J.Y. The pivotal role of TBK1 in inflammatory responses mediated by macrophages. Mediat. Inflamm. 2012, 2012, 979105. [CrossRef]

6. Christgen, S.; Place, D.E.; Kanneganti, T.D. Toward targeting inflammasomes: Insights into their regulation and activation. Cell Res. 2020, 30, 315-327. [CrossRef]

7. Xue, Y.; Enosi Tuipulotu, D.; Tan, W.H.; Kay, C.; Man, S.M. Emerging Activators and Regulators of Inflammasomes and Pyroptosis. Trends Immunol. 2019, 40, 1035-1052. [CrossRef]

8. Yi, Y.S. Caspase-11 non-canonical inflammasome: A critical sensor of intracellular lipopolysaccharide in macrophage-mediated inflammatory responses. Immunology 2017, 152, 207-217. [CrossRef] [PubMed]

9. Yi, Y.S. Regulatory Roles of the Caspase-11 Non-Canonical Inflammasome in Inflammatory Diseases. Immune Netw. 2018, 18 , e41. [CrossRef] [PubMed]

10. Yi, Y.S. Caspase-11 Non-Canonical Inflammasome: Emerging Activator and Regulator of Infection-Mediated Inflammatory Responses. Int. J. Mol. Sci. 2020, 21, 2376. [CrossRef]

11. Yi, Y.S. Functional crosstalk between non-canonical caspase-11 and canonical NLRP3 inflammasomes during infection-mediated inflammation. Immunology 2020, 159, 142-155. [CrossRef] [PubMed]

12. Yi, Y.S. Role of inflammasomes in inflammatory autoimmune rheumatic diseases. Korean J. Physiol. Pharmacol. Off. J. Korean Physiol. Soc. Korean Soc. Pharmacol. 2018, 22, 1-15. [CrossRef] [PubMed]

13. Yi, Y.S. Flavonoids: Nutraceuticals for Rheumatic Diseases via Targeting of Inflammasome Activation. Int. J. Mol. Sci. 2021, 22, 488. [CrossRef]

14. Yi, Y.S. Roles of ginsenosides in inflammasome activation. J. Ginseng Res. 2019, 43, 172-178. [CrossRef] [PubMed]

15. Christgen, S.; Kanneganti, T.D. Inflammasomes and the fine line between defense and disease. Curr. Opin. Immunol. 2020, 62, 39-44. [CrossRef] [PubMed]

16. Boxberger, N.; Hecker, M.; Zettl, U.K. Dysregulation of Inflammasome Priming and Activation by MicroRNAs in Human Immune-Mediated Diseases. J. Immunol. 2019, 202, 2177-2187. [CrossRef]

17. Liu, J.; Qian, C.; Cao, X. Post-Translational Modification Control of Innate Immunity. Immunity 2016, 45, 15-30. [CrossRef]

18. Chen, S.; Yang, J.; Wei, Y.; Wei, X. Epigenetic regulation of macrophages: From homeostasis maintenance to host defense. Cell. Mol. Immunol. 2020, 17, 36-49. [CrossRef]

19. Yang, J.; Liu, Z.; Xiao, T.S. Post-translational regulation of inflammasomes. Cell. Mol. Immunol. 2017, 14, 65-79. [CrossRef]

20. Lopez-Castejon, G. Control of the inflammasome by the ubiquitin system. FEBS J. 2020, 287, 11-26. [CrossRef]

21. Shim, D.W.; Lee, K.H. Posttranslational Regulation of the NLR Family Pyrin Domain-Containing 3 Inflammasome. Front. Immunol. 2018, 9, 1054. [CrossRef]

22. Copeland, R.A. Protein methyltransferase inhibitors as precision cancer therapeutics: A decade of discovery. Philos. Trans. R. Soc. London. Ser. B Biol. Sci. 2018, 373. [CrossRef]

23. Lyko, F. The DNA methyltransferase family: A versatile toolkit for epigenetic regulation. Nat. Rev. Genet. 2018, 19, 81-92. [CrossRef] [PubMed]

24. Guo, S.; Xu, L.; Chang, C.; Zhang, R.; Jin, Y.; He, D. Epigenetic Regulation Mediated by Methylation in the Pathogenesis and Precision Medicine of Rheumatoid Arthritis. Front. Genet. 2020, 11, 811. [CrossRef] [PubMed]

25. Kaniskan, H.U.; Martini, M.L.; Jin, J. Inhibitors of Protein Methyltransferases and Demethylases. Chem. Rev. 2018, 118, 989-1068. [CrossRef]

26. Kim, J.H.; Yoo, B.C.; Yang, W.S.; Kim, E.; Hong, S.; Cho, J.Y. The Role of Protein Arginine Methyltransferases in Inflammatory Responses. Mediat. Inflamm. 2016, 2016, 4028353. [CrossRef]

27. Husmann, D.; Gozani, O. Histone lysine methyltransferases in biology and disease. Nat. Struct. Mol. Biol. 2019, 26, 880-889. [CrossRef] [PubMed]

28. Hyun, K.; Jeon, J.; Park, K.; Kim, J. Writing, erasing and reading histone lysine methylations. Exp. Mol. Med. 2017, 49, e324. [CrossRef]

29. Nimura, K.; Ura, K.; Kaneda, Y. Histone methyltransferases: Regulation of transcription and contribution to human disease. J. Mol. Med. 2010, 88, 1213-1220. [CrossRef]

30. Zhang, J.; Jing, L.; Li, M.; He, L.; Guo, Z. Regulation of histone arginine methylation/demethylation by methylase and demethylase (Review). Mol. Med. Rep. 2019, 19, 3963-3971. [CrossRef]

31. Migliori, V.; Phalke, S.; Bezzi, M.; Guccione, E. Arginine/lysine-methyl/methyl switches: Biochemical role of histone arginine methylation in transcriptional regulation. Epigenomics 2010, 2, 119-137. [CrossRef] [PubMed]

32. Litt, M.; Qiu, Y.; Huang, S. Histone arginine methylations: Their roles in chromatin dynamics and transcriptional regulation. Biosci. Rep. 2009, 29, 131-141. [CrossRef] [PubMed] 
33. Hamamoto, R.; Saloura, V.; Nakamura, Y. Critical roles of non-histone protein lysine methylation in human tumorigenesis. Nat. Rev. Cancer 2015, 15, 110-124. [CrossRef]

34. Biggar, K.K.; Li, S.S. Non-histone protein methylation as a regulator of cellular signalling and function. Nat. Rev. Mol. Cell Biol. 2015, 16, 5-17. [CrossRef] [PubMed]

35. Rodriguez-Paredes, M.; Lyko, F. The importance of non-histone protein methylation in cancer therapy. Nat. Rev. Mol. Cell Biol. 2019, 20, 569-570. [CrossRef]

36. Levy, D. Lysine methylation signaling of non-histone proteins in the nucleus. Cell. Mol. Life Sci. CMLS 2019, 76, 2873-2883. [CrossRef]

37. Gowher, H.; Jeltsch, A. Correction: Mammalian DNA methyltransferases: New discoveries and open questions. Biochem. Soc. Trans. 2019, 47, 959. [CrossRef]

38. Jin, Z.; Liu, Y. DNA methylation in human diseases. Genes Dis. 2018, 5, 1-8. [CrossRef] [PubMed]

39. Ahsan, M.; Ek, W.E.; Rask-Andersen, M.; Karlsson, T.; Lind-Thomsen, A.; Enroth, S.; Gyllensten, U.; Johansson, A. The relative contribution of DNA methylation and genetic variants on protein biomarkers for human diseases. PLoS Genet. 2017,13 , e1007005. [CrossRef] [PubMed]

40. Mittelstrass, K.; Waldenberger, M. DNA methylation in human lipid metabolism and related diseases. Curr. Opin. Lipidol. 2018, 29, 116-124. [CrossRef]

41. Zouali, M. DNA methylation signatures of autoimmune diseases in human B lymphocytes. Clin. Immunol. 2021, $222,108622$. [CrossRef]

42. Berim, A.; Gang, D.R. Production of methoxylated flavonoids in yeast using ring A hydroxylases and flavonoid Omethyltransferases from sweet basil. Appl. Microbiol. Biotechnol. 2018, 102, 5585-5598. [CrossRef]

43. Park, M.R.; Chen, X.; Lang, D.E.; Ng, K.K.S.; Facchini, P.J. Heterodimeric O-methyltransferases involved in the biosynthesis of noscapine in opium poppy. Plant J. Cell Mol. Biol. 2018, 95, 252-267. [CrossRef] [PubMed]

44. Zhu, M.; Zeng, X.; Jiang, Y.; Fan, X.; Chao, S.; Cao, H.; Zhang, W. Determination of arsenic speciation and the possible source of methylated arsenic in Panax Notoginseng. Chemosphere 2017, 168, 1677-1683. [CrossRef] [PubMed]

45. Vance, D.E. Phospholipid methylation in mammals: From biochemistry to physiological function. Biochim. Biophys. Acta 2014, 1838, 1477-1487. [CrossRef]

46. Verkerke, A.R.P.; Ferrara, P.J.; Lin, C.T.; Johnson, J.M.; Ryan, T.E.; Maschek, J.A.; Eshima, H.; Paran, C.W.; Laing, B.T.; Siripoksup, P.; et al. Phospholipid methylation regulates muscle metabolic rate through $\mathrm{Ca}(2+)$ transport efficiency. Nat. Metab. 2019, 1, 876-885. [CrossRef]

47. Zhang, J.; Zheng, Y.G. SAM/SAH Analogs as Versatile Tools for SAM-Dependent Methyltransferases. ACS Chem. Biol. 2016, 11, 583-597. [CrossRef]

48. Katz, J.E.; Dlakic, M.; Clarke, S. Automated identification of putative methyltransferases from genomic open reading frames. Mol. Cell. Proteom. MCP 2003, 2, 525-540. [CrossRef] [PubMed]

49. Soshnev, A.A.; Josefowicz, S.Z.; Allis, C.D. Greater Than the Sum of Parts: Complexity of the Dynamic Epigenome. Mol. Cell 2018, 69, 533. [CrossRef] [PubMed]

50. Allis, C.D.; Jenuwein, T. The molecular hallmarks of epigenetic control. Nat. Rev. Genet. 2016, 17, 487-500. [CrossRef]

51. Schubeler, D. Function and information content of DNA methylation. Nature 2015, 517, 321-326. [CrossRef] [PubMed]

52. Jeong, M.; Goodell, M.A. New answers to old questions from genome-wide maps of DNA methylation in hematopoietic cells. Exp. Hematol. 2014, 42, 609-617. [CrossRef]

53. He, Y.; Ecker, J.R. Non-CG Methylation in the Human Genome. Annu. Rev. Genom. Hum. Genet. 2015, 16, 55-77. [CrossRef]

54. Tough, D.F.; Tak, P.P.; Tarakhovsky, A.; Prinjha, R.K. Epigenetic drug discovery: Breaking through the immune barrier. Nat. Rev. Drug Discov. 2016, 15, 835-853. [CrossRef]

55. Hwang, J.Y.; Aromolaran, K.A.; Zukin, R.S. Author Correction: The emerging field of epigenetics in neurodegeneration and neuroprotection. Nat. Rev. Neurosci. 2018, 19, 771. [CrossRef] [PubMed]

56. Lu, W.; Zhang, R.; Jiang, H.; Zhang, H.; Luo, C. Computer-Aided Drug Design in Epigenetics. Front. Chem. 2018, 6, 57. [CrossRef] [PubMed]

57. Duenas-Gonzalez, A.; Medina-Franco, J.L.; Chavez-Blanco, A.; Dominguez-Gomez, G.; Fernandez-de Gortari, E. Developmental DNA methyltransferase inhibitors in the treatment of gynecologic cancers. Expert Opin. Pharmacother. 2016, 17, 323-338. [CrossRef]

58. Sacconnay, L.; Angleviel, M.; Randazzo, G.M.; Queiroz, M.M.; Queiroz, E.F.; Wolfender, J.L.; Carrupt, P.A.; Nurisso, A. Computational studies on sirtuins from Trypanosoma cruzi: Structures, conformations and interactions with phytochemicals. PLoS Negl. Trop. Dis. 2014, 8, e2689. [CrossRef]

59. Law, J.A.; Jacobsen, S.E. Establishing, maintaining and modifying DNA methylation patterns in plants and animals. Nat. Rev. Genet. 2010, 11, 204-220. [CrossRef]

60. Ponger, L.; Li, W.H. Evolutionary diversification of DNA methyltransferases in eukaryotic genomes. Mol. Biol. Evol. 2005, 22, 1119-1128. [CrossRef]

61. Huff, J.T.; Zilberman, D. Dnmt1-independent CG methylation contributes to nucleosome positioning in diverse eukaryotes. Cell 2014, 156, 1286-1297. [CrossRef] 
62. Klein, C.J.; Botuyan, M.V.; Wu, Y.; Ward, C.J.; Nicholson, G.A.; Hammans, S.; Hojo, K.; Yamanishi, H.; Karpf, A.R.; Wallace, D.C.; et al. Mutations in DNMT1 cause hereditary sensory neuropathy with dementia and hearing loss. Nat. Genet. 2011, 43, 595-600. [CrossRef]

63. Baets, J.; Duan, X.; Wu, Y.; Smith, G.; Seeley, W.W.; Mademan, I.; McGrath, N.M.; Beadell, N.C.; Khoury, J.; Botuyan, M.V.; et al. Defects of mutant DNMT1 are linked to a spectrum of neurological disorders. Brain J. Neurol. 2015, 138, 845-861. [CrossRef]

64. Tatton-Brown, K.; Seal, S.; Ruark, E.; Harmer, J.; Ramsay, E.; Del Vecchio Duarte, S.; Zachariou, A.; Hanks, S.; O’Brien, E.; Aksglaede, L.; et al. Mutations in the DNA methyltransferase gene DNMT3A cause an overgrowth syndrome with intellectual disability. Nat. Genet. 2014, 46, 385-388. [CrossRef] [PubMed]

65. Xu, G.L.; Bestor, T.H.; Bourc'his, D.; Hsieh, C.L.; Tommerup, N.; Bugge, M.; Hulten, M.; Qu, X.; Russo, J.J.; Viegas-Pequignot, E. Chromosome instability and immunodeficiency syndrome caused by mutations in a DNA methyltransferase gene. Nature 1999, 402, 187-191. [CrossRef]

66. Wei, D.; Loeken, M.R. Increased DNA methyltransferase 3b (Dnmt3b)-mediated CpG island methylation stimulated by oxidative stress inhibits expression of a gene required for neural tube and neural crest development in diabetic pregnancy. Diabetes 2014, 63, 3512-3522. [CrossRef] [PubMed]

67. Baylin, S.B.; Jones, P.A. A decade of exploring the cancer epigenome-Biological and translational implications. Nat. Rev. Cancer 2011, 11, 726-734. [CrossRef] [PubMed]

68. Heyn, H.; Esteller, M. DNA methylation profiling in the clinic: Applications and challenges. Nat. Rev. Genet. 2012, 13, 679-692. [CrossRef]

69. Jones, P.A.; Issa, J.P.; Baylin, S. Targeting the cancer epigenome for therapy. Nat. Rev. Genet. 2016, 17, 630-641. [CrossRef] [PubMed]

70. Ramadoss, M.; Mahadevan, V. Targeting the cancer epigenome: Synergistic therapy with bromodomain inhibitors. Drug Discov. Today 2018, 23, 76-89. [CrossRef]

71. Copeland, R.A.; Solomon, M.E.; Richon, V.M. Protein methyltransferases as a target class for drug discovery. Nat. Rev. Drug Discov. 2009, 8, 724-732. [CrossRef]

72. Kwiatkowski, S.; Drozak, J. Protein Histidine Methylation. Curr. Protein Pept. Sci. 2020, 21, 675-689. [CrossRef] [PubMed]

73. Bergo, M.O.; Leung, G.K.; Ambroziak, P.; Otto, J.C.; Casey, P.J.; Young, S.G. Targeted inactivation of the isoprenylcysteine carboxyl methyltransferase gene causes mislocalization of K-Ras in mammalian cells. J. Biol. Chem. 2000, 275, 17605-17610. [CrossRef]

74. Yang, W.S.; Yeo, S.G.; Yang, S.; Kim, K.H.; Yoo, B.C.; Cho, J.Y. Isoprenyl carboxyl methyltransferase inhibitors: A brief review including recent patents. Amino Acids 2017, 49, 1469-1485. [CrossRef] [PubMed]

75. Finley, A.; Copeland, R.A. Small molecule control of chromatin remodeling. Chem. Biol. 2014, 21, 1196-1210. [CrossRef]

76. Wilson, C.B.; Rowell, E.; Sekimata, M. Epigenetic control of T-helper-cell differentiation. Nat. Rev. Immunol. 2009, 9, 91-105. [CrossRef]

77. Jones, P.A.; Baylin, S.B. The epigenomics of cancer. Cell 2007, 128, 683-692. [CrossRef]

78. Esteller, M. Cancer epigenomics: DNA methylomes and histone-modification maps. Nat. Rev. Genet. 2007, 8, 286-298. [CrossRef] [PubMed]

79. Jansson, M.; Durant, S.T.; Cho, E.C.; Sheahan, S.; Edelmann, M.; Kessler, B.; La Thangue, N.B. Arginine methylation regulates the p53 response. Nat. Cell Biol. 2008, 10, 1431-1439. [CrossRef]

80. Liu, Q.; Wang, M.W. Histone lysine methyltransferases as anti-cancer targets for drug discovery. Acta Pharmacol. Sin. 2016, 37, 1273-1280. [CrossRef]

81. Li, J.; Zhu, S.; Ke, X.X.; Cui, H. Role of several histone lysine methyltransferases in tumor development. Biomed. Rep. 2016, 4, 293-299. [CrossRef] [PubMed]

82. Tsankova, N.; Renthal, W.; Kumar, A.; Nestler, E.J. Author Correction: Epigenetic regulation in psychiatric disorders. Nat. Rev. Neurosci. 2019, 20, 187-188. [CrossRef] [PubMed]

83. Ketelut-Carneiro, N.; Fitzgerald, K.A. Inflammasomes. Curr. Biol. CB 2020, 30, R689-R694. [CrossRef]

84. Yun, M.; Yi, Y.S. Regulatory roles of ginseng on inflammatory caspases, executioners of inflammasome activation. J. Ginseng Res. 2020, 44, 373-385. [CrossRef] [PubMed]

85. Mathur, A.; Hayward, J.A.; Man, S.M. Molecular mechanisms of inflammasome signaling. J. Leukoc. Biol. 2018, 103, 233-257. [CrossRef]

86. Saxena, M.; Yeretssian, G. NOD-Like Receptors: Master Regulators of Inflammation and Cancer. Front. Immunol. $2014,5,327$. [CrossRef]

87. Yeretssian, G. Effector functions of NLRs in the intestine: Innate sensing, cell death, and disease. Immunol. Res. 2012, 54, 25-36. [CrossRef] [PubMed]

88. Corridoni, D.; Arseneau, K.O.; Cifone, M.G.; Cominelli, F. The dual role of nod-like receptors in mucosal innate immunity and chronic intestinal inflammation. Front. Immunol. 2014, 5, 317. [CrossRef]

89. Martinon, F.; Burns, K.; Tschopp, J. The inflammasome: A molecular platform triggering activation of inflammatory caspases and processing of proIL-beta. Mol. Cell 2002, 10, 417-426. [CrossRef]

90. Choubey, D. Type I interferon (IFN)-inducible Absent in Melanoma 2 proteins in neuroinflammation: Implications for Alzheimer's disease. J. Neuroinflamm. 2019, 16, 236. [CrossRef] 
91. Kayagaki, N.; Warming, S.; Lamkanfi, M.; Vande Walle, L.; Louie, S.; Dong, J.; Newton, K.; Qu, Y.; Liu, J.; Heldens, S.; et al. Non-canonical inflammasome activation targets caspase-11. Nature 2011, 479, 117-121. [CrossRef]

92. Hagar, J.A.; Powell, D.A.; Aachoui, Y.; Ernst, R.K.; Miao, E.A. Cytoplasmic LPS activates caspase-11: Implications in TLR4independent endotoxic shock. Science 2013, 341, 1250-1253. [CrossRef] [PubMed]

93. Kayagaki, N.; Wong, M.T.; Stowe, I.B.; Ramani, S.R.; Gonzalez, L.C.; Akashi-Takamura, S.; Miyake, K.; Zhang, J.; Lee, W.P.; Muszynski, A.; et al. Noncanonical inflammasome activation by intracellular LPS independent of TLR4. Science 2013, 341, 1246-1249. [CrossRef] [PubMed]

94. Shi, J.; Zhao, Y.; Wang, Y.; Gao, W.; Ding, J.; Li, P.; Hu, L.; Shao, F. Inflammatory caspases are innate immune receptors for intracellular LPS. Nature 2014, 514, 187-192. [CrossRef]

95. Matikainen, S.; Nyman, T.A.; Cypryk, W. Function and Regulation of Noncanonical Caspase-4/5/11 Inflammasome. J. Immunol. 2020, 204, 3063-3069. [CrossRef]

96. Mazgaeen, L.; Gurung, P. Recent Advances in Lipopolysaccharide Recognition Systems. Int. J. Mol. Sci. 2020, 21, 379. [CrossRef]

97. Ding, J.; Shao, F. SnapShot: The Noncanonical Inflammasome. Cell 2017, 168, 544. [CrossRef] [PubMed]

98. De Carvalho, R.V.H.; Andrade, W.A.; Lima-Junior, D.S.; Dilucca, M.; de Oliveira, C.V.; Wang, K.; Nogueira, P.M.; Rugani, J.N.; Soares, R.P.; Beverley, S.M.; et al. Leishmania Lipophosphoglycan Triggers Caspase-11 and the Non-canonical Activation of the NLRP3 Inflammasome. Cell Rep. 2019, 26, 429-437. [CrossRef]

99. Zanoni, I.; Tan, Y.; Di Gioia, M.; Broggi, A.; Ruan, J.; Shi, J.; Donado, C.A.; Shao, F.; Wu, H.; Springstead, J.R.; et al. An endogenous caspase-11 ligand elicits interleukin-1 release from living dendritic cells. Science 2016, 352, 1232-1236. [CrossRef]

100. Gabrielli, E.; Pericolini, E.; Luciano, E.; Sabbatini, S.; Roselletti, E.; Perito, S.; Kasper, L.; Hube, B.; Vecchiarelli, A. Induction of caspase- 11 by aspartyl proteinases of Candida albicans and implication in promoting inflammatory response. Infect. Immun. 2015, 83, 1940-1948. [CrossRef]

101. O'Donoghue, E.J.; Krachler, A.M. Mechanisms of outer membrane vesicle entry into host cells. Cell. Microbiol. 2016, 18, 1508-1517. [CrossRef]

102. Vanaja, S.K.; Russo, A.J.; Behl, B.; Banerjee, I.; Yankova, M.; Deshmukh, S.D.; Rathinam, V.A.K. Bacterial Outer Membrane Vesicles Mediate Cytosolic Localization of LPS and Caspase-11 Activation. Cell 2016, 165, 1106-1119. [CrossRef]

103. Gegner, J.A.; Ulevitch, R.J.; Tobias, P.S. Lipopolysaccharide (LPS) signal transduction and clearance. Dual roles for LPS binding protein and membrane CD14. J. Biol. Chem. 1995, 270, 5320-5325. [CrossRef]

104. Deng, M.; Tang, Y.; Li, W.; Wang, X.; Zhang, R.; Zhang, X.; Zhao, X.; Liu, J.; Tang, C.; Liu, Z.; et al. The Endotoxin Delivery Protein HMGB1 Mediates Caspase-11-Dependent Lethality in Sepsis. Immunity 2018, 49, 740-753. [CrossRef]

105. Yokoyama, S.; Cai, Y.; Murata, M.; Tomita, T.; Yoneda, M.; Xu, L.; Pilon, A.L.; Cachau, R.E.; Kimura, S. A novel pathway of LPS uptake through syndecan-1 leading to pyroptotic cell death. eLife 2018, 7. [CrossRef]

106. Meunier, E.; Dick, M.S.; Dreier, R.F.; Schurmann, N.; Kenzelmann Broz, D.; Warming, S.; Roose-Girma, M.; Bumann, D.; Kayagaki, N.; Takeda, K.; et al. Caspase-11 activation requires lysis of pathogen-containing vacuoles by IFN-induced GTPases. Nature 2014, 509, 366-370. [CrossRef] [PubMed]

107. Wandel, M.P.; Kim, B.H.; Park, E.S.; Boyle, K.B.; Nayak, K.; Lagrange, B.; Herod, A.; Henry, T.; Zilbauer, M.; Rohde, J.; et al. Guanylate-binding proteins convert cytosolic bacteria into caspase-4 signaling platforms. Nat. Immunol. 2020, $21,880-891$. [CrossRef] [PubMed]

108. Cerqueira, D.M.; Gomes, M.T.R.; Silva, A.L.N.; Rungue, M.; Assis, N.R.G.; Guimaraes, E.S.; Morais, S.B.; Broz, P.; Zamboni, D.S.; Oliveira, S.C. Guanylate-binding protein 5 licenses caspase-11 for Gasdermin-D mediated host resistance to Brucella abortus infection. PLoS Pathog. 2018, 14, e1007519. [CrossRef] [PubMed]

109. Rivers-Auty, J.; Brough, D. Potassium efflux fires the canon: Potassium efflux as a common trigger for canonical and noncanonical NLRP3 pathways. Eur. J. Immunol. 2015, 45, 2758-2761. [CrossRef]

110. Xu, Z.; Chen, Z.M.; Wu, X.; Zhang, L.; Cao, Y.; Zhou, P. Distinct Molecular Mechanisms Underlying Potassium Efflux for NLRP3 Inflammasome Activation. Front. Immunol. 2020, 11, 609441. [CrossRef]

111. Greenberg, M.V.C.; Bourc'his, D. The diverse roles of DNA methylation in mammalian development and disease. Nat. Rev. Mol. Cell Biol. 2019, 20, 590-607. [CrossRef]

112. Tang, S.C.; Yeh, J.I.; Hung, S.J.; Hsiao, Y.P.; Liu, F.T.; Yang, J.H. Glycolic Acid Silences Inflammasome Complex Genes, NLRC4 and ASC, by Inducing DNA Methylation in HaCaT Cells. DNA Cell Biol. 2016, 35, 124-134. [CrossRef] [PubMed]

113. Wei, M.; Wang, L.; Wu, T.; Xi, J.; Han, Y.; Yang, X.; Zhang, D.; Fang, Q.; Tang, B. NLRP3 Activation Was Regulated by DNA Methylation Modification during Mycobacterium tuberculosis Infection. BioMed Res. Int. 2016, 2016, 4323281. [CrossRef]

114. Haldar, S.; Dru, C.; Mishra, R.; Tripathi, M.; Duong, F.; Angara, B.; Fernandez, A.; Arditi, M.; Bhowmick, N.A. Histone deacetylase inhibitors mediate DNA damage repair in ameliorating hemorrhagic cystitis. Sci. Rep. 2016, 6, 39257. [CrossRef]

115. Huang, Y.H.; Lo, M.H.; Cai, X.Y.; Kuo, H.C. Epigenetic hypomethylation and upregulation of NLRC4 and NLRP12 in Kawasaki disease. Oncotarget 2018, 9, 18939-18948. [CrossRef] [PubMed]

116. Zhong, W.; Li, B.; Xu, Y.; Yang, P.; Chen, R.; Wang, Z.; Shao, C.; Song, J.; Yan, J. Hypermethylation of the Micro-RNA 145 Promoter Is the Key Regulator for NLRP3 Inflammasome-Induced Activation and Plaque Formation. JACC Basic Transl. Sci. 2018, 3 , 604-624. [CrossRef] [PubMed]

117. Sun, X.; Xiao, L.; Chen, J.; Chen, X.; Chen, X.; Yao, S.; Li, H.; Zhao, G.; Ma, J. DNA methylation is involved in the pathogenesis of osteoarthritis by regulating CtBP expression and CtBP-mediated signaling. Int. J. Biol. Sci. 2020, 16, 994-1009. [CrossRef] 
118. Zhai, Z.; Samson, J.M.; Yamauchi, T.; Vaddi, P.K.; Matsumoto, Y.; Dinarello, C.A.; Ravindran Menon, D.; Fujita, M. Inflammasome Sensor NLRP1 Confers Acquired Drug Resistance to Temozolomide in Human Melanoma. Cancers 2020, 12, 2518. [CrossRef]

119. Abplanalp, W.T.; Cremer, S.; John, D.; Hoffmann, J.; Schuhmacher, B.; Merten, M.; Rieger, M.A.; Vasa-Nicotera, M.; Zeiher, A.M.; Dimmeler, S. Clonal Hematopoiesis-Driver DNMT3A Mutations Alter Immune Cells in Heart Failure. Circ. Res. 2021, 128, 216-228. [CrossRef]

120. Yu, J.T.; Hu, X.W.; Chen, H.Y.; Yang, Q.; Li, H.D.; Dong, Y.H.; Zhang, Y.; Wang, J.N.; Jin, J.; Wu, Y.G.; et al. DNA methylation of FTO promotes renal inflammation by enhancing m(6)A of PPAR-alpha in alcohol-induced kidney injury. Pharmacol. Res. 2021, 163, 105286. [CrossRef]

121. Jambhekar, A.; Dhall, A.; Shi, Y. Roles and regulation of histone methylation in animal development. Nat. Rev. Mol. Cell Biol. 2019, 20, 625-641. [CrossRef] [PubMed]

122. Greer, E.L.; Shi, Y. Histone methylation: A dynamic mark in health, disease and inheritance. Nat. Rev. Genet. 2012, 13, 343-357. [CrossRef]

123. Song, Y.; $\mathrm{Wu}, \mathrm{F} . ; \mathrm{Wu}$, J. Targeting histone methylation for cancer therapy: Enzymes, inhibitors, biological activity and perspectives. J. Hematol. Oncol. 2016, 9, 49. [CrossRef]

124. Nielsen, A.L.; Jorgensen, P.; Lerouge, T.; Cervino, M.; Chambon, P.; Losson, R. Nizp1, a novel multitype zinc finger protein that interacts with the NSD1 histone lysine methyltransferase through a unique C2HR motif. Mol. Cell. Biol. 2004, 24, 5184-5196. [CrossRef]

125. Rayasam, G.V.; Wendling, O.; Angrand, P.O.; Mark, M.; Niederreither, K.; Song, L.; Lerouge, T.; Hager, G.L.; Chambon, P.; Losson, R. NSD1 is essential for early post-implantation development and has a catalytically active SET domain. EMBO J. 2003, 22, 3153-3163. [CrossRef]

126. Lucio-Eterovic, A.K.; Singh, M.M.; Gardner, J.E.; Veerappan, C.S.; Rice, J.C.; Carpenter, P.B. Role for the nuclear receptor-binding SET domain protein 1 (NSD1) methyltransferase in coordinating lysine 36 methylation at histone 3 with RNA polymerase II function. Proc. Natl. Acad. Sci. USA 2010, 107, 16952-16957. [CrossRef]

127. Sakhon, O.S.; Victor, K.A.; Choy, A.; Tsuchiya, T.; Eulgem, T.; Pedra, J.H. NSD1 mitigates caspase-1 activation by listeriolysin O in macrophages. PLoS ONE 2013, 8, e75911. [CrossRef] [PubMed]

128. Ancelin, K.; Lange, U.C.; Hajkova, P.; Schneider, R.; Bannister, A.J.; Kouzarides, T.; Surani, M.A. Blimp1 associates with Prmt5 and directs histone arginine methylation in mouse germ cells. Nat. Cell Biol. 2006, 8, 623-630. [CrossRef]

129. Gyory, I.; Wu, J.; Fejer, G.; Seto, E.; Wright, K.L. PRDI-BF1 recruits the histone H3 methyltransferase G9a in transcriptional silencing. Nat. Immunol. 2004, 5, 299-308. [CrossRef] [PubMed]

130. Yu, J.; Angelin-Duclos, C.; Greenwood, J.; Liao, J.; Calame, K. Transcriptional repression by blimp-1 (PRDI-BF1) involves recruitment of histone deacetylase. Mol. Cell. Biol. 2000, 20, 2592-2603. [CrossRef]

131. Shi, F.; Yang, Y.; Kouadir, M.; Xu, W.; Hu, S.; Wang, T. Inflammasome-independent role of NLRP12 in suppressing colonic inflammation regulated by Blimp-1. Oncotarget 2016, 7, 30575-30584. [CrossRef]

132. Sanders, N.L.; Mishra, A. Role of interleukin-18 in the pathophysiology of allergic diseases. Cytokine Growth Factor Rev. 2016, 32, 31-39. [CrossRef]

133. Papale, A.; Kummer, E.; Galbiati, V.; Marinovich, M.; Galli, C.L.; Corsini, E. Understanding chemical allergen potency: Role of NLRP12 and Blimp-1 in the induction of IL-18 in human keratinocytes. Arch. Toxicol. 2017, 91, 1783-1794. [CrossRef]

134. Xiao, T.S. The nucleic acid-sensing inflammasomes. Immunol. Rev. 2015, 265, 103-111. [CrossRef]

135. Coulon, P.G.; Dhanushkodi, N.; Prakash, S.; Srivastava, R.; Roy, S.; Alomari, N.I.; Nguyen, A.M.; Warsi, W.R.; Ye, C.; Carlos-Cruz, E.A.; et al. NLRP3, NLRP12, and IFI16 Inflammasomes Induction and Caspase-1 Activation Triggered by Virulent HSV-1 Strains Are Associated With Severe Corneal Inflammatory Herpetic Disease. Front. Immunol. 2019, 10, 1631. [CrossRef] [PubMed]

136. Zheng, D.; Liwinski, T.; Elinav, E. Inflammasome activation and regulation: Toward a better understanding of complex mechanisms. Cell Discov. 2020, 6, 36. [CrossRef]

137. Roy, A.; Dutta, D.; Iqbal, J.; Pisano, G.; Gjyshi, O.; Ansari, M.A.; Kumar, B.; Chandran, B. Nuclear Innate Immune DNA Sensor IFI16 Is Degraded during Lytic Reactivation of Kaposi's Sarcoma-Associated Herpesvirus (KSHV): Role of IFI16 in Maintenance of KSHV Latency. J. Virol. 2016, 90, 8822-8841. [CrossRef] [PubMed]

138. Roy, A.; Ghosh, A.; Kumar, B.; Chandran, B. IFI16, a nuclear innate immune DNA sensor, mediates epigenetic silencing of herpesvirus genomes by its association with H3K9 methyltransferases SUV39H1 and GLP. eLife 2019, 8. [CrossRef] [PubMed] 